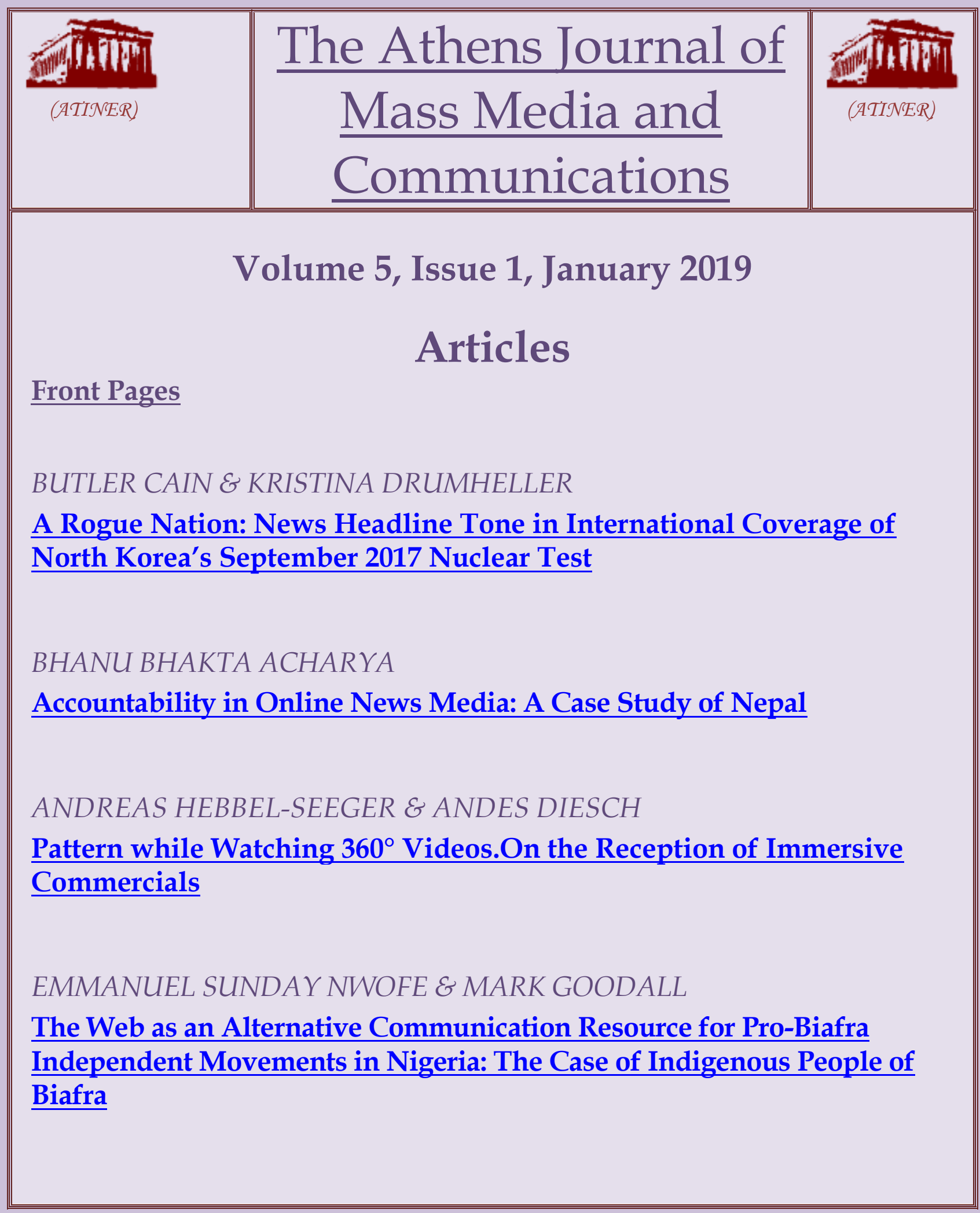




\section{Mission}

ATINER is a World Non-Profit Association of Academics and Researchers based in Athens. ATINER is an independent Association with a Mission to become a forum where Academics and Researchers from all over the world can meet in Athens, exchange ideas on their research and discuss future developments in their disciplines, as well as engage with professionals from other fields. Athens was chosen because of its long history of academic gatherings, which go back thousands of years to Plato's Academy and Aristotle's Lyceum. Both these historic places are within walking distance from ATINER's downtown offices. Since antiquity, Athens was an open city. In the words of Pericles, Athens"... is open to the world, we never expel a foreigner from learning or seeing". ("Pericles' Funeral Oration", in Thucydides, The History of the Peloponnesian War). It is ATINER's mission to revive the glory of Ancient Athens by inviting the World Academic Community to the city, to learn from each other in an environment of freedom and respect for other people's opinions and beliefs. After all, the free expression of one's opinion formed the basis for the development of democracy, and Athens was its cradle. As it turned out, the Golden Age of Athens was in fact, the Golden Age of the Western Civilization. Education and (Re)searching for the 'truth' are the pillars of any free (democratic) society. This is the reason why Education and Research are the two core words in ATINER's name. 
The Athens Journal of Mass Media and

Communications

ISSN NUMBER: 2407-9677 - DOI: 10.30958/ajmmc

Volume 5, Issue 1, January 2019

Download the entire issue ( $\underline{\mathrm{PDF}})$

Front Pages

i-viii

A Rogue Nation: News Headline Tone in International 1 Coverage of North Korea's September 2017 Nuclear $\underline{\text { Test }}$

Butler Cain \& Kristina Drumheller

Accountability in Online News Media: A Case Study of 17 Nepal

Bhanu Bhakta Acharya

Pattern while Watching $360^{\circ}$ Videos.On the Reception

of Immersive Commercials

Andreas Hebbel-Seeger \& Andes Diesch

The Web as an Alternative Communication Resource for

51

Pro-Biafra Independent Movements in Nigeria: The

Case of Indigenous People of Biafra

Emmanuel Sunday Nwofe \& Mark Goodall 


\section{The Athens Journal of Mass Media and Communications Editorial and Reviewers' Board}

$\underline{\text { Editors }}$

- Dr. Yorgo Pasadeos, Director, Social Sciences Division, ATINER \& Professor Emeritus, University of Alabama USA.

- Dr. Patrick Vyncke, Professor of Communication Management, Department of Communication Sciences, Ghent University, Belgium.

\section{Editorial Board}

- Dr. John Pavlik, Head, Mass Media and Communication Unit, ATINER \& Professor, Rutgers University, USA.

- Dr. Burak Dogu, Academic Member, ATINER \& Vice Dean, Izmir University of Economics, Turkey.

- Dr. Andzela Armoniene, Head of The Fund Young Researcher, Lithuania.

- Dr. Mariam Gersamia, Professor \& Head, Division of Journalism and Mass Communication, Ivane Javakhishvili Tbilisi State University, Georgia.

- Dr. Egle Jaskuniene, Associate Professor \& Vice Dean for Research, Faculty of Creative Industries, Vilnius Gediminas Technical University, Lithuania.

- Dr. Berrin Yanikkaya, Academic Member, ATINER and Professor \& Head, School of Communication Studies, Auckland University of Technology, New Zealand.

- Dr. Dali Osepashvili, Professor, Department of Journalism and Mass Communication, Ivane Javakhishvili Tbilisi State University, Georgia.

- Dr. Walter Wymer, Academic Member, ATINER \& Professor of Marketing, University of Lethbridge, Canada.

- Dr. Alan Albarran, Academic Member, ATINER \& Professor, The University of North Texas, USA.

- Dr. Patricia L. Dooley, Elliott Distinguished Professor of Communication, Wichita State University, USA.

- Dr. Catherine Ann Collins, Professor, Department of Rhetoric, Willamette University, USA.

- Dr. Pamela Doyle Tran, Professor of Electronic News, University of Alabama, USA.

- Dr. S. Andrews, Professor, Department of Information Technology, Mahendra Engineering College, India.

- Dr. Emmanuel Ngwainmbi, Department of Communication Studies, The University of North Carolina, USA.

- Dr. Zsolt Alfred Polgar, Academic Member, ATINER \& Associate Professor, Technical University of Cluj-Napoca, Romania.

- Dr. Margaret M. Cassidy, Academic Member, ATINER \& Associate Professor, Adelphi University, USA. 
- Dr. Baris Coban, Associate Professor, Communication Sciences Department, Dogus University, Turkey.

- Dr. Ulas Basar Gezgin, Associate Professor of Applied Communication, British University Vietnam, Vietnam.

- Dr. Anya Luscombe, Associate Professor and Head, Department of Academic Core, University College Roosevelt, The Netherlands.

- Dr. Charles Obot, Academic Member, ATINER \& Associate Professor, University of Uyo, Nigeria.

- Dr. Ceren Sozeri, Associate Professor, Faculty of Communication, Galatasaray University, Turkey.

- Dr. Matthew D. Matsaganis, Assistant Professor, Department of Communication, State University of New York (SUNY), USA.

- Dr. Geneviève A. Bonin, Assistant Professor, University of Ottawa, Canada.

- Dr. Klarissa Lueg, Assistant Professor, Aarhus University, Denmark.

- Dr. George Pavlou, Assistant Professor, European University, Cyprus.

- Dr. Yolandi Slabbert, Senior Lecturer, Department of Communication Science, University of South Africa, South Africa.

- Dr. Daniel Binns, Academic Member, ATINER \& Lecturer, RMIT University, Australia.

- Dr. Binoy Kampmark, Lecturer in Social Sciences, School of Global, Urban and Social Studies, RMIT University, Australia.

- Dr. Sarah Sparke, Academic Member, ATINER \& Research Associate, CMIR, University of the West of England, UK.

- Dr. Vittoria Sacco, Postdoctoral Assistant, Neuchatel University, Switzerland.

- Ms. Mania Alehpour, PhD Candidate, University of Tehran, Iran.

- General Managing Editor of all ATINER's Publications: Ms. Afrodete Papanikou

- ICT Managing Editor of all ATINER's Publications: Mr. Kostas Spyropoulos

- Managing Editor of this Journal: Ms. Zoi Charalampous (bio)

\section{Reviewers' Board}

Click Here 


\section{President's Message}

All ATINER's publications including the e-journals are open access without any costs (submission, processing, publishing, open access paid by authors, open access paid by readers etc) and are independent of the presentations made at any of the many small events (conferences, symposiums, forums, colloquiums, courses, roundtable discussions) organized by ATINER throughout the year. The intellectual property rights of the submitted papers remain with the author.

Before you submit, please make sure your paper meets some basic academic standards, which include proper English. Some articles will be selected from the numerous papers that have been presented at the various annual international academic conferences organized by the different divisions and units of the Athens Institute for Education and Research.

The plethora of papers presented every year will enable the editorial board of each journal to select the best ones, and in so doing, to produce a quality academic journal. In addition to papers presented, ATINER encourages the independent submission of papers to be evaluated for publication.

The current issue of the The Athens Journal of Mass Media and Communications (AJMMC) is the first issue of the fifth volume (2019). The reader will notice some changes compared with the previous issues, which I hope is an improvement.

Gregory T. Papanikos, President

Athens Institute for Education and Research 


\section{Athens Institute for Education and Research}

A World Association of Academics and Researchers

17th Annual International Conference on Communication and Mass Media, 13-16 May 2019, Athens, Greece

The Mass Media \& Communication Research Unit of the Athens Institute for Education and Research (ATINER) organizes its 17 th Annual International Conference on Communication and Mass Media, 13-16 May 2019, Athens, Greece sponsored by the Athens Journal of Mass Media and Communications. The aim of the conference is to bring together academics and researchers of Communications, Mass Media and other related disciplines. Please submit a proposal using the form available (https://www.atiner.gr/2019/FORM-MED.doc).

- Abstract Submission: 1 April 2019

- Acceptance of Abstract: 4 Weeks after Submission

- Submission of Paper: 15 April 2019

\section{Academic Members Responsible for the Conference}

- Dr. John Pavlik, Head, Mass Media and Communication Research Unit, ATINER \& Professor, Rutgers University, USA.

- Dr. Yorgo Pasadeos, Director, Social Sciences Division, ATINER \& Professor Emeritus, University of Alabama USA.

\section{Social and Educational Program}

The Social Program Emphasizes the Educational Aspect of the Academic Meetings of Atiner.

- Greek Night Entertainment (This is the official dinner of the conference)

- Athens Sightseeing: Old and New-An Educational Urban Walk

- Social Dinner

- Mycenae Visit

- Exploration of the Aegean Islands

- Delphi Visit

- Ancient Corinth and Cape Sounion

\section{Conference Fees}

Conference fees vary from $400 €$ to $2000 €$ Details can be found at: https://www.atiner.gr/2019fees 


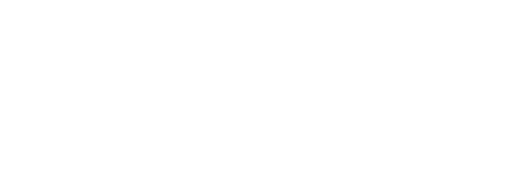




\title{
A Rogue Nation: News Headline Tone in International Coverage of North Korea's September 2017 Nuclear Test
}

\begin{abstract}
By Butler Cain ${ }^{*} \&$ Kristina Drumheller ${ }^{\dagger}$
On September 3, 2017, North Korea underwent its sixth nuclear test despite expectations of denuclearization. News headlines from six international news sources were analyzed for journalistic tone related to the nuclear test. As with previous research on earlier tests, headlines were primarily neutral or negative regardless of the news source. Given that $60 \%$ of people only read the headlines, and a similar number share news stories on social media based on headline, examining journalistic tone in headlines during international crises is worthwhile.
\end{abstract}

Keywords: Korea, nuclear, headline, tone, journalism.

\section{Introduction}

News coverage of North Korea's continued thwarting of denuclearization efforts has often ranged from neutral reporting of events to negative condemnation with little to no positive commentary (Cain \& Drumheller, 2014). North Korea's sixth nuclear test on September 3, 2017, brought variations in headlines from news organizations around the world. News headlines might be all that is read of a news story as headlines are highlighted in email briefs and social media shares. This study analyzes the news headlines from six international broadcasters on the day of the detonation and examines them for journalistic tone to assess agenda setting trends set by the limited but salient information a headline provides.

The relationship the United States has with North Korea has long been one of proximity through maintaining a base in South Korea and policy demand in the form of CVID (complete, verifiable, and irreversible denuclearization; Anderson, 2017). Despite demands from the US, sanctions, and withheld aid, North Korea's intention to weaponize in the 1980s has grown in scale and technical prowess with each nuclear test (Anderson, 2017). North Korea conducted its sixth nuclear test detonating "a nuclear device that was vastly more powerful than its last" (Fifield, 2017, para. 2). Global news coverage of the event began soon afterward and international condemnation was swift ("North Korean Nuclear," 2017).

This was the first nuclear test of the Trump presidency, testing the administration's claims of low tolerance for any aggression coming from North Korea. Former US Secretary of State Rex Tillerson gave no clear policy indication in spring 2017 but stated "a different approach is required" (Graham, 2017, "March 16" para. 1) and "the policy of strategic patience has ended" (Graham, 2017, "March 17" para. 1). While Tillerson vacillated between no policy and

${ }^{*}$ Chair and Associate Professor, Department of Communications, University of North Alabama, USA.

†Professor, Department of Communication, West Texas A\&M University, USA. 
resuming talks, Trump stated his expectations that China should solve the problem or the US will, while also indicating there could be "a major, major conflict with North Korea" (Graham, 2017, "April 27" para. 1). In April 2018, Mike Pompeo was sworn in as Tillerson's replacement, and on May 10, President Trump announced plans to meet with North Korean leader Kim Jong-un in Singapore to discuss plans to curb North Korea's nuclear weapons program (Nakamura \& Wagner, 2018). In an apparent effort to support Kim Jong-un's pledge to stop all nuclear testing, North Korea invited journalists to witness the May 24 destruction of the country's nuclear testing site at Punggye-ri, where all six of North Korea's nuclear tests were conducted (Hass \& Borger, 2018). However, just hours later, President Trump announced that the summit was being canceled because of recent rhetoric from the North Korean government (Borger \& Hass, 2018). By June 1, however, the summit was again on the schedule for June 12. In preparing for the historic meeting, Secretary of State Pompeo stated publicly that US objectives were "the complete, and verifiable, and irreversible denuclearization of the Korean Peninsula" (Rosenfeld, 2018, para. 7). After the June 12 summit, President Trump said he "believed that Mr. Kim's desire to end North Korea's seven-decade-old confrontation with the United States was sincere" (Landler, 2018, para. 3). Meeting with Kim Jong-un once again in October 2018, Pompeo announced that North Korea was willing to allow inspectors into the nuclear testing site the country claimed it blew up in late May 2018. In November, South Korea's Yonhap news agency reported that Kim was also considering allowing international inspectors to visit North Korea's main nuclear complex (Johnson, 2018).

\section{Rationale}

For decades, world leaders have had to contend with the isolationist and dictatorial tactics of North Korea and its leaders who have not engaged in diplomacy - the leaders have not seemed to care much about what anyone thinks. Surprisingly, there is little research on the news coverage of North Korea and its actions. Jung and Park (2014) mapped Twitter-mediated interpersonal communication networks to analyze how homeland security benefits from crowdsourced information. Jiang (2006) analyzed cross-cultural differences in questions and responses between journalists and spokespersons at press conferences in the US and Japan regarding the North Korean nuclear tests, but this study had little to do with North Korea other than as a context for coding responses. Similar to this study, Cain and Drumheller (2014) analyzed the agenda setting and tone evident in newspaper headlines related to North Korea's fourth nuclear test. Most research, however, comes out of fields in international affairs, analyzing policy and strategy of world leaders from the US, South Korea, and China, in particular (e.g., Anderson, 2017; Cho, 2017; Hong, 2017; Oh \& Hassig, 2010). Although the politics behind North Korean tensions are important, media representations should not be overlooked given their role in framing arguments for the public. 
The authors have done similar research on newspaper coverage of North Korean nuclear tests and more needs to be done, including expanding into other media such as international broadcast news. The journalistic tone developed through headlines alone can be important when measuring attitudes toward national policy. The American Press Institute reported in 2014 that only $40 \%$ of Americans reported reading beyond a news headline ("How Americans get," 2014), while another study reported that $59 \%$ of shared article URLs were never clicked (Gabielkov et al., 2016). This points to a trend in journalistic consumption that should be explored.

\section{Literature Review}

\section{North Korea's Nuclear Program Since 2013}

Cain and Drumheller's (2014) analysis of agenda setting and tone in coverage of North Korea's third nuclear test on February 12, 2013, contains a brief history of the country's nuclear program up to that month. In April of that year, the Democratic People's Republic of Korea (DPRK), which is the North's official name, announced plans to "restart all facilities at its main Yongbyon nuclear complex" ("North Korea Profile," 2017). In March 2014, the country "warned it was preparing to test another nuclear device" (McKirdy \& Kim, 2014), and it followed that warning in May 2015 with a claim that it had "developed technology to mount [a] nuclear warhead on a missile" (S. Kim, 2017). North Korea confirmed in September 2015 that it had restarted its Yongbyon nuclear plant ("North Korea Profile," 2017), and the following January the country announced it had conducted its fourth nuclear test since 2006 - a hydrogen bomb - though international experts doubted the claim (McCurry \& Safi, 2016). Two months later, the country's state-run news organization reported North Korea had "miniaturized nuclear warheads to fit on ballistic missiles" (Almasy \& McKirdy, 2016). On September 9, 2016, North Korea conducted its fifth nuclear test, a 10kiloton explosion causing seismic activity registering 5.3 in magnitude (Erickson, 2017). Nearly one year later, the DPRK engaged in its sixth test.

\section{Policy and Positioning}

In reviewing the headlines news organizations use to report on North Korea's nuclear tests, it is important to understand the policies and positions in North Korea's tensions with the United States. For years the US and North Korea have entered into agreements easily broken by North Korea (Cain \& Drumheller, 2014). In 2003, the Agreed Framework of 1994 collapsed and the US, Japan, South Korea, and China provided incentives such as construction and energy supplies for North Korea to denuclearize (Oh \& Hassig, 2010). Yet, North Korea tested its first nuclear device in 2006, its second in 2009, and in 2013, North Korea ran its third test and announced it would no longer discuss denuclearization regardless of UN sanctions imposed (Cain \& Drumheller, 2014). The current US president has used 
more aggressive rhetoric than previous politicians (Hong, 2017), yet North Korea did not seem initially moved by the president's tone, running its sixth nuclear test despite warnings. The seemingly improved, yet still uncertain climate between two aggressive opponents potentially affects the responses out of North Korea and mediated reports.

North Korea has had an historically poor economy, relying on food subsidies for the poor largely due to elite and military extravagances (Oh \& Hassig, 2010). Despite these struggles, North Korea's economy does appear to be experiencing a $1 \%$ to 5\% annual growth (M.F., 2017). Sanctions placed on the country are often targeted to affect the elite and military spending. Despite bans on doing business with North Korea, many still do enter trade agreements without much risk of the UN following up with secondary sanctions (M.F., 2017). This economic growth has likely empowered North Korea in demonstrating its increasing military power as well.

Cho (2017) makes an interesting argument that nuclear testing is part of North Korea's attempts at national branding in contrast to "liberal capitalist governments" (p. 616). Although national branding has traditionally been thought of as a promotion tactic with positive messages to highlight a positive image of a nation, Cho (2017) contends that nations can use national branding more ontologically to identify larger questions of being to "contribute to nation building processes, particularly when the country in question feels it lacks either legitimacy from inside or recognition from outside, as may be the case in a dictatorship" (p. 595). North Korea does not attempt to create a favorable image, but rather one more threatening, using spectacles such as the Arirang Festival, a large celebration of the ruling party with propagandized themes, and military displays, such as nuclear tests. The nuclear tests, thus, become a "political showcase" (p. 609) as North Korea follows verbal threats with literal explosions. In this, global press coverage can fulfill the purpose by fueling interest and speculation.

As for the previous failed attempts at halting North Korea's nuclear testing, Anderson (2017) argues that on one side are those arguing that it is a problem of policy and on the other a problem of personality. He argues, however, that it is "the simple fact of US power and its position on the peninsula through the USRepublic of Korea alliance" (p. 623) that largely motivates North Korean's nuclear decisions. As long as the US maintains a position in South Korea, North Korea will not abandon its nuclear efforts, forcing the US to choose between stalemate and denuclearization, making CVID ineffective foreign policy. Anderson (2017) further suggests that dropping CVID could allow the US to focus on other areas such as human rights conditions.

In a similar fashion, Roy (2017) argues that there are four common misunderstandings that affect policy decisions:

First, characterizations of the regime as irrational are wrong. ...Second, paranoid about subversion. ...Third, the option of using military action to prevent North Korea from getting nuclear missiles is not "on the table." ...Finally, depending on China to solve the problem is fruitless because the Chinese fear a collapse of the regime more than they fear a nuclear-armed North Korea. (p. 2) 
North Korea seeks intimidation tactics and strongly distrusts democratic countries, so it is unlikely to give up its nuclear weapons in exchange for greater economic opportunities. Prior to Cho (2017) and Anderson (2017), Oh and Hassig (2010) argued that "in the absence of economic strength and trusted allies, the country must keep its military strong" (p. 96) to maintain power. As is clearly true today, North Korea would rather be a country with nuclear potential than actually trigger a war (Hong, 2017; Oh \& Hassig, 2010). It is interesting that the proximity of the US is simultaneously to protect against North Korean aggressions yet likely the reason for them as well. This duality of structure creates the opportunities and constraints for strategic responses by national leaders. Further, despite this relationship, the greatest risk is to South Korea, which has very limited input aside from being located at North Korea's border.

\section{Journalistic Tone}

As noted in the rationale, a majority of social media users share content that has not been read, making headlines fairly powerful. DeMers (2016) argues that the measure of an article's performance comes down to the headline: it might be the reason you read, do not read, or do not read but still share. Headlines contribute to the echo chamber when it supports beliefs, and some publishers write headlines expecting this very phenomenon. There are notable problems including a less informed and easily manipulated populace (DeMers, 2016) resulting from language choices used by a headline writer who might not even be the journalist who wrote the article.

These headline writers, whether editor or journalist, serve an agenda-setting function, influencing the news in snippets rather than fully investigated narratives. Agenda-setting has two primary levels: what to think about and how the public should think about those issues (McCombs, 2004; Sheafer, 2007). It is possible for headlines and their news stories to actually take the reader in different directions. Andrew (2007) found a "considerable difference between articles and their headlines in terms of emphasis and issue salience" with tone often changing between the headline and story (p. 24). When the agenda is truncated to headlines, there are clear implications for information flow and processing.

Research on valence of print news stories has included editorial views influencing the overall tone of news stories on political candidates (Druckman \& Parkin, 2005; Kahn \& Kenney, 2002), positively valenced tendencies toward military stories (Pfau et al., 2004), and a more positive tone from female journalists than males covering South Korea's female cabinet members (Kim \& Yoon, 2008). Limited research has been done on headlines alone, yet such analysis can extend our understanding of the agenda setting function as we acknowledge that it does not even take a full news story to form attitudes and opinions on a topic. This can be especially problematic in advocating or condemning political antagonistic maneuvering. Thus, this paper asks the following:

RQ: How do headlines of major broadcast news organizations set the journalistic tone in the case of North Korea's nuclear tests? 
The following sections outline the method and analysis followed by a discussion of the findings.

\section{Methodology}

The authors employed a method similar to the one they used for their previous examination of how newspapers covered North Korea's nuclear test in 2013 (Cain \& Drumheller, 2014). This study is a descriptive content analysis of 38 news headlines from six international television broadcasters: $B B C$ World, headquartered in the United Kingdom; Voice of America, based in the United States; Channel NewsAsia, located in Singapore; NHK World, headquartered in Japan; Arirang TV, based in South Korea; and China Global Television Network, located in China. The headlines come from Sept. 3, the day of the event. These six international broadcasters were deliberately chosen because of their geographic proximity to, or their host nations' political interest in, North Korea's nuclear capabilities. Specifically, Arirang TV, NHK World, and China Global Television Network are each based in northeast Asia, where North Korea is located. Channel NewsAsia was chosen because of its coverage of the entire Asia region. BBC World and Voice of America were included because they have a history of covering North Korea's nuclear program and are based in Western countries whose governments have been critical of North Korea's efforts. Finally, each broadcaster provides information in English, which is the authors' native language. The search term "nuclear" was used to identify reports on all six broadcasters' websites for their respective Sept. 3 coverage, and stories not specifically related to that day's nuclear test were excluded. All reports were obtained on Sept. 7, 2017, and to ensure continued access to the data, they were saved to the first author's computer desktop as .HTM files. News articles came from each of the following primary news sites: Arirang $T V$ (http://www.arirang.com/index.asp); NHK World (https://www3.nhk.or.jp/nhk world/); China Global Television Network America (https://america.cgtn.com/); Channel NewsAsia (http://www.channelnewsasia.com-/news); BBC World (http:// www.bbc.com/news/world); and Voice of America (https://www.voanews.com/). The first author examined the headlines to determine their journalistic tone. An example of negative tone would be using a word such as "condemn" or implying negative consequences as a result of North Korea's nuclear test. A headline that reported favorably upon, or implied favorable results because of, North Korea's test would be an example of positive tone. A basic statement of fact would represent neutral tone. The second author served for peer review, examining the first author's analysis and categorizations.

\section{Analysis}

The authors were somewhat surprised by the number of stories featured on websites belonging to news organizations located in Asia. Arirang TV (South Korea) featured five reports on its website for Sept. 3, while NHK World (Japan) 
contained only two. Considering each country's proximity to North Korea and their respective governments' consistent condemnation of the DPRK's nuclear activities, the authors expected to find more stories on these organizations' websites. Conversely, despite being located in the Asian nation farthest away from North Korea in this study, Channel NewsAsia (Singapore) featured the most stories of any news operation with 14. China Global Television Network (China) contained only two reports of the nuclear test on its China Global Television Network America website, which was not surprising considering China's balancing act of remaining North Korea's strongest ally while also recognizing mounting international frustration with the North's nuclear activities. BBC World (United Kingdom) featured 10 reports, and Voice of America (United States) had five.

\section{South Korea, Japan, and China}

Three of Arirang TV's five headlines from Sept. 3 exhibited neutral tone. "South Korea's political parties convene emergency meetings following North Korea's presumed nuclear test" (M. Kim, 2017) was published shortly before 2:30 p.m. Korean Standard Time (KST). Less than two hours later, the next story headline suggested the South Korean government had confirmed the test: "N. Korea conducts apparent 6th nuclear test: S Korea" (H. Kim, 2017). Less than a minute later, the headline "Seismic data indicate North Korea's strongest nuclear test to date" was published (M. Y. Kim, 2017). A little more than an hour later, after 5 p.m. KST, Arirang TV posted a story on its website with the following headline: "South Korean President Calls for the 'Strongest Possible' Response to North Korea's nuclear test" (Moon, 2017). The phrase "strongest possible" exhibits negative tone, indicating that South Korea has been compelled yet again to respond to the North's nuclear activities with increasingly forceful language. Arirang TV's second headline to exhibit negative tone suggested North Korea's nuclear test humiliated China's president. "N. Korea's sixth nuclear test embarasses [sic] Chinese President Xi Jinping as he hosts BRICS summit meeting" (C. Kim, 2017) was the fourth headline published in Arirang TV's fivestory sequence.

Both headlines from NHK World were journalistically neutral. "S. Korean media reports on possible nuclear test" ("S. Korean Media," 2017) and "S. Korea military suggested North may test new tech" ("S. Korea Military, " 2017) were published without a reporter's byline. The two headlines featured on China Global Television Network America's website focused either on responses from the United Nations and United States or from Russia. The first headline published that afternoon contained a negative tone. "Xi, Putin agree to appropriately deal with DPRK's nuclear test" ("Xi, Putin agree" 2017) suggests China and Russia would work together to address North Korea's nuclear activities. The phrase "deal with" is typically used to describe a problematic or difficult situation. The second headline of the day, "DPRK nuclear test: UN Security Council to host emergency meeting, Trump admin responds" (Barton, 2017), was journalistically neutral and focused on the immediate responses from the United Nations and United States. 


\section{Singapore}

All but one of Channel NewsAsia's 14 published headlines came from two international news services: Reuters and Agence France-Presse (AFP). Six of the 14 exhibited neutral tone. "North Korea Announces successful hydrogen bomb test hours after tremors" ("North Korea announces," 2017), "On Chinese border, North Korea nuclear test shakes ground, but not routines" ("On Chinese Border," 2017), and "North Korea says conducts hydrogen bomb test, Trump to meet with advisers" ("North Korea says," 2017) were produced by Reuters and published on Channel NewsAsia's website. The other three neutral-toned headlines were produced by AFP: "North Korean missile development: A timeline" ("North Korean Missile," 2017), "UN Security Council to meet on North Korea nuclear test" ("UN Secretary Council," 2017), and "North Korea's top newsreader announces H-bomb success" ("North Korea's Top," 2017).

Seven headlines exhibited negative tone, and three of these included a version of the word "condemn" within them. "China 'strongly condemns North Korean nuclear test': Foreign ministry" ("China," 2017) and "North Korea nuclear test draws swift international condemnation" ("North Korea Nuclear Test Draws," 2017) were produced by AFP and published on Channel NewsAsia's website. The third headline focused on the response from Singapore's government: "Singapore 'strongly condemns' North Korea nuclear test: MFA" ("Singapore," 2017). This was the only published report on Channel NewsAsia's website included in this study that was not produced by either Reuters or AFP. Another AFP-produced headline quoted Japan's prime minister, who described North Korea's nuclear test as "absolutely unacceptable" ("N Korea Nuclear Test," 2017). The Reutersproduced headline "China's anger at West to overshadow tougher action on North Korea" (Blanchard \& Wen, 2017) implies that North Korea has exposed China to increased pressure from western nations to address North Korea's nuclear activities in a meaningful way. Similar to one published on China Global Television Network America's website, Channel NewsAsia included a Reuters headline indicating that China and Russia would "appropriately deal" with North Korea's nuclear test (Blanchard, 2017). The final negatively-toned headline from $A F P$, "North Korea and its nuclear test: What next?" ("North Korea and its Nuclear Test," 2017), implicitly addresses a common theme that the DPRK's government is unpredictable and defies international norms. The one Channel NewsAsia headline that could be perceived as having either a positive or negative tone regarding North Korea was attached to a report by Reuters: "Is North Korea's hydrogen bomb a 'game changer'?" ("Is North Korea's," 2017). Positively, it could be interpreted as an indication of the country's newly-acquired status as a true global nuclear power. Negatively, it could be interpreted as a dire watershed event for the rest of the world.

\section{United States}

Among the five headlines written for Voice of America, two were journalistically neutral, two included a negative reference to North Korea, and one 
could be viewed favorably or negatively regarding the country's apparent stronger influence in global affairs. "North Korea conducts sixth nuclear test" (Herman, 2017) and "North Korea: Sixth nuclear test was an H-bomb for ICBM" (Padden \& Herman, 2017) provide basic facts about the DPRK's nuclear detonation and were published during the early morning hours in the United States. However, two very similar headlines published later that afternoon exhibited negative tone when they quoted President Donald Trump referring to North Korea as a "rogue nation" (Bredemeier, Padden, \& Herman, 2017; Harton, 2017). Finally, a news analysis headline provided what could be interpreted as a positive or negative assessment of North Korea's technological achievement and what that could mean for the country's global standing. "ANALYSIS - Possible two-stage hydrogen bomb seen 'game changer' for North Korea" ("ANALYSIS," 2017) was produced by Reuters but was published on Voice of America's website several hours after North Korea's nuclear test. A similar headline displayed on Channel NewsAsia's website included the phrase "game changer," and as noted above, a positive interpretation could indicate a new level of influence for North Korea that has been reserved only for the world's nuclear powers, whereas a negative interpretation could indicate North Korea's now greater threat to global stability.

\section{Great Britain}

Six of the Sept. 3 headlines featured on BBC World's website were neutral in tone. "Kim inspects 'nuclear warhead': A picture decoded" (Hanham, 2017) featured photos of Kim Jong-un, North Korea's supreme leader, examining a nuclear warhead. The photos had been publicly released a few hours before North Korea's nuclear test. Another headline maintained a similar theme of trying to analyze an event with scant information: "North Korea nuclear test: 'Tunnel collapse' may provide clues" (Dill, 2017). One headline indicated BBC World had collected a list of "The most powerful nuclear blasts ever" ("The Most Powerful," 2017), while another report was simply titled "North Korea nuclear test - latest updates" and had featured a live reporting feed on the day of the test (Lawson \& Baker, 2017). The other two neutral headlines referred to the detonated weapon as being capable of fitting onto a missile: "North Korea 'has missile-ready nuclear weapon"' ("North Korea 'has Missile-ready," 2017) and "North Korea nuclear test: Hydrogen bomb 'missile-ready'" ("North Korea Nuclear Test: Hydrogen," 2017).

Three of BBC World's headlines were phrased as questions. "North Korea nuclear tests: What did they achieve?" ("North Korea Nuclear Tests," 2017) exhibited neutral tone and was used for an article that highlighted North Korea's previous nuclear achievements. However, the other two interrogative headlines suggested negative tone. "Nuclear N Korea: How worried should we be?" ("Nuclear N Korea," 2017) implicitly references the country's reputation as an unpredictable international pariah. "North Korea's nuclear tests: How should Trump respond?" (Nilsson-Wright, 2017) suggests the president of the United States is obligated to address yet another provocation from North Korea's government. The final headline also exhibits negative tone when addressing the United States' potential response. "North Korea nuclear test: Lindsey Graham 
warns of US attack" ("North Korea Nuclear Test: Lindsey," 2017) suggests the DPRK's nuclear ambitions are a threat to US security.

\section{Discussion}

The majority of the news headlines exhibited neutral tone. This might be due largely to the timeline chosen. The news closest to the event is more likely to contain factual information. Although not surprising that early headlines might be neutral, the repeated offense of the North Korean government could support immediate value judgments from either journalists themselves or those interviewed. It is actually a bit refreshing to find most headlines attempting to provide facts over speculation or condemnation as the first reports of the nuclear test filtered through the international news media system.

When examining the tone of 60 lead paragraphs in newspaper coverage of North Korea's 2013 nuclear test, Cain and Drumheller (2014) identified 42 of them $(70 \%)$ as negative. The authors expected a similar finding with broadcast headlines but only $39 \%$ had a definitive negative tone. Although there are several potential reasons for the differences, the uncertain times could be reflected through uncertainty over reporting. Rather than feeling comfortable condemning with certainty, some headlines appeared as if the news organizations were awaiting the US response, with even one headline asking "How should Trump respond?" These types of headlines might not only convey a bit of felt uncertainty, but might even set the agenda for public voices providing input for an indefinite future where North Korean denuclearization policy is concerned.

An interesting added agenda setting issue is the cultural implications of noting US uncertainty, embarrassment of Chinese leadership, and game changing moves by North Korea. These headlines taken together illustrate the power and position arguments of Anderson (2017) while calling into question hanging any hopes on Trump to bring peace (Hong, 2017) in a way that does not ultimately harm South Korea. China's embarrassment is largely because it has not been in their best interest to act against North Korea (Roy, 2017) and continued nuclear detonations only put China's power into question. As long as the US is positionally a threat to North Korea's power, nuclear detonations and missile launches are likely to continue.

\section{Conclusion}

The expectation of a similar percentage of negative headlines found in Cain and Drumheller's (2014) previous work carried over into this research, but that is not what the authors found. Of the 38 news headlines examined from Sept. 3, 2017 , only 15 of them (39\%) were identified as exhibiting negative tone. The number reaches $45 \%$ when including the two headlines that could be interpreted either as positive or negative in tone. There could be several likely causes for this. The previous study focused on four newspapers, two from South Korea and two 
from the United States, and included one week's worth of reporting. Because the governments of both countries oppose North Korea's nuclear efforts, it was not a surprise that newspapers located in South Korea and the United States depicted the DPRK negatively. This study, however, contained news headlines from only one day - the first day of the event - creating the possibility that the authors could have identified more headlines exhibiting negative tone as news coverage continued to examine the nuclear event and global reactions to it. Another possibility for the lower percentage of negatively-toned headlines could be that the news outlets examined for this study are international broadcasters from six different countries and are trying to appeal to a wider global audience by adopting a more neutral journalistic tone. Related to this, one potential limitation of this study is that all six news organizations use the English language and are clearly aiming to attract an English-speaking audience. If these headlines had been written in each respective country's native language or languages for a localized audience, the results may have been different. Another potential limitation that was not explored in this study is whether the tone of the headlines matches the tone of the lead paragraphs.

This study also does not account for the historical, political, and cultural expectations that may directly or indirectly influence each news organization. All news media in China are owned by the Communist Party of China and the Chinese government (Weaver \& Willnat, 2012), so it is expected that China Global Television Network will report on topics that the Chinese government deems acceptable and will avoid those topics considered taboo. Singapore does not have the same type of press freedom exercised in democratic nations, but its government also does not exert total control of all media (Weaver \& Willnat, 2012), meaning Channel NewsAsia is potentially subject to political pressure regarding what it broadcasts or publishes. NHK World is part of Nippon Hoso Kyokai (NHK), or Japan Broadcasting Corporation. It is Japan's only public broadcasting organization, and its stated mission is to inform the world about the latest developments in Japan and Asia ("About NHK," n.d.). Arirang TV is a public service agency in South Korea with a mission to enhance Korea's international image ("Company Profile," n.d.). It would not be unusual to expect story selection and presentation for both $N H K$ World and Arirang TV to be influenced by those mission statements, particularly when their respective host countries view North Korea as a threat. The same idea holds for Voice of America, whose mission statement includes the idea that "the long-range interests of the United States are served by communicating directly with the peoples of the world" ("Mission and Values," n.d., para. 5). The British Broadcasting Corporation, which includes $B B C$ World, is generally considered to be the public broadcasting model to which all other broadcasters are compared. Still, being situated in a western country that is often at odds with North Korea may influence the $B B C$ 's tone of coverage related to the DPRK.

Future academic research should examine journalistic coverage of North Korea beyond the typical narratives related to its nuclear program. News media coverage of North Korea's human rights abuses would be fertile grounds for exploration. The country's institutionalized propaganda machine remains worthy of academic analysis, as well. Additional studies of how coverage of North Korea 
is presented by news organizations in other countries would provide interesting insights, particularly if the organization's home country considers itself an ally of North Korea.

With so many people sharing headlines without even clicking article links, headlines carry more responsibility than in the past. It is no longer news stories alone setting agendas, it is often solely on the support of a single headline. This should be a cautionary tale to journalists and editors that the weight of what the world thinks about may not be resting on investigative journalism, but on cleverlywritten headlines.

\section{Bibliography}

About NHK World. (n.d.). NHK World. Retrieved from https://bit.ly/2FrUB10.

Almasy, S., \& McKirdy, E. (2016, Mar. 10). North Korea Claims to have Nuclear Warheads that can fit on Missiles. CNN. Retrieved from https://cnn.it/2D4mjzx.

ANALYSIS - Possible Two-stage Hydrogen Bomb seen 'Game Changer' for North Korea. (2017, Sept. 3). Voice of America. Retrieved from https://bit.ly/2wwThoM.

Anderson, N. D. (2017). Explaining North Korea's Nuclear Ambitions: Power and Position on the Korean Peninsula. Australian Journal of International Affairs, 71(6), 621-641.

Andrew, B. (2007). Media Generated Shortcuts: Do Newspaper Headlines Present another Roadblock for Low-information Rationality? Press/Politics, 12(2), 24-43.

Barton, J. (2017, Sept. 3). DPRK Nuclear test: UN Security Council to Host Emergency Meeting, Trump Admin Responds. CGTN America. Retrieved from https://bit.ly/ 2QGR9kY.

Blanchard, B. (2017, Sept. 3). Xi, Putin Agree to 'Appropriately Deal' with North Korea Nuclear Test: Xinhua. Channel NewsAsia. Retrieved from https://bit.ly/2RMTIMw.

Blanchard, B., \& Wen, P. (2017, Sept. 3). China's Anger at West to Overshadow Tougher Action on North Korea. Channel NewsAsia. Retrieved from https://bit.ly/2soBzRn.

Borger, J., \& Hass, B. (2018, May 24). Donald Trump Cancels North Korea Nuclear Summit. The Guardian. Retrieved from https://bit.ly/2x7JrvT.

Bredemeier, K., Padden, B., \& Herman, S. (2017, Sept. 3). Trump Calls North Korea a 'Rogue Nation' after its Sixth Nuclear Test. Voice of America. Retrieved from https://bit.ly/2wxCj9Z.

Cain, B., \& Drumheller, K. (2014). Broken Promises: Agenda Setting and Tone in News Stories about North Korea's Nuclear Program. GSTF Journal on Media \& Communications, 2(1), 34-39.

China 'Strongly Condemns North Korean Nuclear Test': Foreign Ministry. (2017, Sept. 3). Channel NewsAsia. Retrieved from https://bit.ly/2vVNSnD.

Cho, E. J. R. (2017). National Branding for Survival in North Korea: The Arirang Festival and Nuclear Weapons Tests. Geopolitics, 22(3), 594-622.

Company Profile. (n.d.). Arirang TV. Retrieved from https://bit.ly/2RqM7hS.

DeMers, J. (2016, Aug. 8). 59 Percent of you will Share this Article without even reading it. Forbes. Retrieved from: https://bit.ly/2FITAIP.

Dill, C. (2017, Sept. 3). North Korea Nuclear Test: 'Tunnel Collapse' may Provide Clues. BBC World. Retrieved from https://bbc.in/2D5SJJC. 
Druckman, J. N., \& Parkin, M. (2005). The Impact of Media Bias: How Editorial Slant Affects Voters. The Journal of Politics, 67(4), 1030-1049.

Erickson, A. (2017, April 14). A Timeline of North Korea's Five Nuclear Tests and how the US has Responded. The Washington Post. Retrieved from https://wapo.st/2VKs $\mathrm{AaO}$.

Fifield, A. (2017, Sept. 3). In Latest Test, North Korea Detonates its most Powerful Nuclear Device yet. The Washington Post. Retrieved from https://wapo.st/2AK4IuX.

Gabielkov, M., Ramachandran, A., Chaintreau, A., \& Legout, A. (2016, June). Social Clicks: What and who gets Read on Twitter? Presented at ACM Sigmetrics/IFIP Performance 2016 in Antibes Juan-les-Pins, France. Retrieved from sigm095gabielkov.pdf.

Graham, D. A. (2017, Apr. 28). The Many North Korea Policies of the Trump Administration: Is the US Ready for War? Does it want Talks? Officials are Sending Mixed Messages. The Atlantic. Retrieved from https://bit.ly/2pdCwLJ.

Hanham, M. (2017, Sept. 3). Kim Inspects 'Nuclear Warhead': A Picture Decoded. BBC World. Retrieved from https://bbc.in/2hSOiq1.

Harton, M. (2017, Sept. 3). President Trump calls North Korea a 'rogue nation' after nuke test. Voice of America. Retrieved from https://bit.ly/2RNLhuU.

Hass, B., \& Borger, J. (2018, May 24). North Korea 'Destroys' Nuclear Test Site as World's Media Watches. The Guardian. Retrieved from https://bit.ly/2QJO5F7.

Herman, S. (2017, Sept. 3). North Korea Conducts Sixth Nuclear Test. Voice of America. Retrieved from https://bit.ly/2gtMqmY.

Hong, S. (2017, July). Trump is the Right Leader to Achieve Peace with North Korea. New Perspectives Quarterly, 34(3), 13-18.

How Americans get their news. (2014, Mar. 7). American Press Institute. Retrieved from https://bit.ly/2VLSWcv.

Is North Korea's Hydrogen Bomb a 'Game Changer'? (2017, Sept. 3). Channel NewsAsia. Retrieved from https://bit.ly/2M5g9lq.

Jiang, X. (2006). Cross-cultural Pragmatic Differences in US and Chinese Press Conferences: The Case of the North Korea Nuclear Crisis. Discourse \& Society, 17(2), 237-257.

Johnson, J. (2018, Nov. 28). North Korea's Kim Reportedly Open to Inspections at main Nyongbyon Nuclear Complex. The Japan Times. Retrieved from https://bit.ly/2D6w MdD.

Jung, K., \& Park, H. W. (2014). Citizens' Social Media use and Homeland Security Information Policy: Some Evidences from Twitter users during the 2013 North Korea Nuclear Test. Government Information Quarterly, 31(4), 563-573.

Kahn, K. F., \& Kenney, P. J. (2002). The Slant of the News: How Editorial Endorsements Influence Campaign Coverage and Citizens' Views of Candidates. The American Political Science Review, 96(2), 381-394.

Kim, C. (2017, Sept. 3). N. Korea's Sixth Nuclear Test Embarasses [sic] Chinese President Xi Jinping as he Hosts BRICS Summit Meeting. Arirang TV. Retrieved from https://bit.ly/2CharbA.

Kim, H. (2017, Sept. 3). N. Korea Conducts Apparent 6th Nuclear Test: S Korea. Arirang $T V$. Retrieved from https://bit.ly/2VKtFzo.

Kim, K., \& Yoon, Y. (2008). The Influence of Journalists' Gender on Newspaper Stories about Women Cabinet Members in South Korea. Asian Journal of Communication, 19(3), 289-301. 
Kim, M. (2017, Sept. 3). South Korea's Political Parties Convene Emergency Meetings Following North Korea's Presumed Nuclear Test. Arirang TV. Retrieved from https://bit.ly/2M4v0MU.

Kim, M. Y. (2017, Sept. 3). Seismic Data Indicate North Korea's Strongest Nuclear Test to Date. Arirang TV. Retrieved from https://bit.ly/2RJwHoi.

Kim, S. (2017, April 15). A Timeline of North Korea's Missile Launches and Nuclear Detonations. Bloomberg. Retrieved from https://bloom.bg/2RJwXDM.

Landler, M. (2018, June 12). The Trump-Kim Summit was Unprecedented, but the Statement was Vague. The New York Times. Retrieved from https://nyti.ms/2t4a0g7.

Lawson, A., \& Baker, V. (2017, Sept. 3). North Korea Nuclear Test - Latest Updates. $B B C$ World. Retrieved from https://bbc.in/2FnfRpl.

M. F. (2017, June 7). The Economist Explains: Why the North Korean Economy is Growing. The Economist. Retrieved from https://econ.st/2AK5po3.

McCombs, M. (2004). Setting the Agenda: The Mass Media and Public Opinion. Cambridge: Polity Press.

McCurry, J., \& Safi, M. (2016, Jan. 6). North Korea Claims Successful Hydrogen Bomb Test in 'Self-defence against US'. The Guardian. Retrieved from https://bit.ly/ 2CffUjl.

McKirdy, E., \& Kim, S. (2014, April 1). Report: N. Korea Fires on South during North's Military Drills; South Responds. CNN. Retrieved from https://cnn.it/PisMLc.

Mission and Values. (n.d.). Voice of America. Retrieved from https://bit.ly/2FrWpqO.

Moon, C. (2017, Sept. 3). South Korean President Calls for the "Strongest Possible" Response to North Korea's nuclear test. Arirang TV. Retrieved from https://bit.ly/ 2M6VwFF.

N Korea Nuclear Test 'Absolutely Unacceptable': Japan PM. (2017, Sept. 3). Channel NewsAsia. Retrieved from https://bit.ly/2FmrNrz.

Nakamura, D., \& Wagner, J. (2018, May 10). Trump announces June 12 summit in Singapore with North Korean leader, US prisoners released. The Washington Post. Retrieved from https://wapo.st/2FtREgk.

Nilsson-Wright, J. (2017, Sept. 3). North Korea's Nuclear Tests: How should Trump Respond? BBC World. Retrieved from https://bbc.in/2RCQ5DB.

North Korea 'has Missile-ready Nuclear Weapon'. (2017, Sept. 3). BBC World. Retrieved from https://bbc.in/2vBvwNt.

North Korea and its Nuclear Test: What next? (2017, Sept. 3). Channel NewsAsia. Retrieved from https://bit.ly/2VMs8ZJ.

North Korea Announces Successful Hydrogen Bomb Test Hours after Tremors. (2017, Sept. 3). Channel NewsAsia. Retrieved from https://bit.ly/2H7MKrT.

North Korea Nuclear Test Draws Swift International Condemnation. (2017, Sept. 3). Channel NewsAsia. Retrieved from https://bit.ly/2D5vFeo.

North Korea Nuclear Test: Hydrogen Bomb 'Missile-ready'. (2017, Sept. 3). BBC World. Retrieved from https://bbc.in/2ez7j3c.

North Korea Nuclear Test: Lindsey Graham Warns of US Attack. (2017, Sept. 3). BBC World. Retrieved from https://bbc.in/2H4ry66.

North Korea Nuclear Tests: What did they Achieve? (2017, Sept. 3). BBC World. Retrieved from https://bbc.in/1OhAe3d.

North Korea Profile. (2017, July). BBC World. Retrieved from https://bbc.in/1FUmaHA.

North Korea says Conducts Hydrogen Bomb Test, Trump to meet with Advisers. (2017, Sept. 3). Channel NewsAsia. Retrieved from https://bit.ly/2FlAp1z.

North Korea's Top Newsreader Announces H-bomb Success. (2017, Sept. 3). Channel NewsAsia. Retrieved from https://bit.ly/2Fo1Zvh. 
North Korean Missile Development: A Timeline. (2017, Sept. 3). Channel NewsAsia. Retrieved from https://bit.ly/2VNVQNF.

North Korean Nuclear Test Prompts Global Condemnation. (2017, Sept. 3). Reuters. Retrieved from https://reut.rs/2Ft6DqR.

Nuclear N Korea: How worried should we be? (2017, Sept. 3). BBC World. Retrieved from https://bbc.in/2AHXDLv.

Oh, K., \& Hassig, R. (2010). North Korea in 2009: The Song Remains the same. Asian Survey, 50(1), 89-96.

On Chinese Border, North Korea Nuclear Test Shakes Ground, but not Routines. (2017, Sept. 3). Channel NewsAsia. Retrieved from https://bit.ly/2AE001O.

Padden, B., \& Herman, S. (2017, Sept. 3). North Korea: Sixth Nuclear Test was an Hbomb for ICBM. Voice of America. Retrieved from https://bit.ly/2wxYJ99.

Pfau, M., Haigh, M., Gettle, M., Donnelly, M., Scott, G., Warr, D., \& Witten, E. (2004). Embedding Journalists in Military Combat Units: Impact on Newspaper Story Frames and Tone. Journalism \& Mass Communication Quarterly, 81(1), 74-88.

Rosenfeld, E. (2018, June 11). Pompeo: We are 'Eager' to see if North Korea is 'Sincere' about its Willingness to Denuclearize. CNBC. Retrieved from https://cnb.cx/2Fo MjrE.

Roy, D. (2017, Aug.). Misunderstanding North Korea. Asia Pacific Issues, (133), 1-8.

S. Korea Military Suggested North may Test New Tech. (2017, Sept. 3). NHK World. Retrieved from https://bit.ly/2SLkAnY.

S. Korean Media Reports on Possible Nuclear Test. (2017, Sept. 3). NHK World. Retrieved from https://bit.ly/2TMRVPD.

Sheafer, T. (2007). How to Evaluate it: The Role of Story-evaluative Tone in Agenda Setting and Priming. Journal of Communication, 57(1), 21-39.

Singapore 'Strongly Condemns' North Korea Nuclear Test: MFA. (2017, Sept. 3). Channel NewsAsia. Retrieved from https://bit.ly/2snpb4f.

The Most Powerful Nuclear Blasts ever. (2017, Sept. 3). BBC World. Retrieved Sept. 7, 2017 from https://bbc.in/2D6zVKt.

UN Security Council to meet on North Korea Nuclear Test. (2017, Sept. 3). Channel NewsAsia. Retrieved from https://bit.ly/2RIbUBD.

Weaver, D., \& Willnat, L. (2012). The Global Journalist in the 20th Century. New York: Routledge.

Xi, Putin agree to Appropriately Deal with DPRK's Nuclear Test. (2017, Sept. 3). CGTN America. Retrieved from https://bit.ly/2HaClwQ. 



\title{
Accountability in Online News Media: A Case Study of Nepal
}

\author{
By Bhanu Bhakta Acharya*
}

\begin{abstract}
Scholars argue that accountability of news media and journalists to the public stakeholders has been improving in the 21st century because of the increased use of digital platforms, which are interactive, immediate, and universal. Since most studies related to online news media accountability have focused on developed countries, this research study examines the state of accountability in online news media in Nepal, where access to online media is very limited and audiences are barely aware of media's journalistic responsibilities. By employing a case study research method with three data sources, and by interpreting the available data using Denis McQuail's four stakeholders of media accountability as a theoretical framework, this research study finds that online media in Nepal, despite having unique features on digital platforms, are less accountable to professional and public stakeholders than their traditional counterparts, such as newspapers and television. The study also finds that Internet accessibility, media literacy, and resource availability are of primary concern in ensuring media accountability in Nepal.
\end{abstract}

Keywords: accountability, digital platforms, media ethics, Nepal, online journalism.

\section{Introduction}

The invention of the Internet and the diffusion of online news media have attracted the attention of scholars worldwide to the issue of accountability on digital platforms. News media scholars have been generally optimistic about the capability of the Internet in assisting with maintaining accountability where journalism is concerned (Deuze and Yeshua, 2001; Fengler, 2012; Friend and Singer, 2007; Heikkila, Domingo, Pies, Glowacki, Kus, and Baisnée, 2012; Joseph, 2011; Kovach and Rosenstiel, 2014; Krogh, 2012; Lasorsa, Seth, Lewis, and Holton, 2012; Plaisance, 2000; Singer, 2005; Ward, 2010). The Internet offers affordable venues (such as blogs, micro-blogs, and discussion forums) for public discourse about journalistic performance in relation to social responsibility. Audiences, largely ignored by traditional media in the past, today, have their own digital platforms for expressing their concerns. In addition, audiences can take part in news production on digital platforms as contributors, sources, or comment providers, and, consequently, create pressure on media to be more accountable to professional and public stakeholders compared to traditional media outlets.

Online news media, despite being around for over two decades, are still considered a new phenomenon among journalists worldwide due to rapid technological changes and developments, as well as mass media convergence on multimedia platforms. These digital platforms have many features (such as universal accessibility, interactivity, and options for public participation) that are useful for upholding public accountability, however, they are not free from professional challenges such as hasty information updates and post-publication

${ }^{*}$ Researcher, University of Ottawa, Canada. 
content modifications (Babcock, 2012; Friend and Singer, 2007; Heikkilä et al., 2012; Kovach and Rosenstiel, 2014). Such challenges may call journalistic performance into question with regard to upholding and maintaining accountability to the public and professionals on digital platforms. The concept of "public stakeholders" refers to the general public that consumes media products, whereas the term "professional stakeholders" refers to media watchdog organizations, such as press councils, ombudspersons, or any other media regulatory body that encourages journalists and media institutions to follow codes of ethics in everyday journalism.

Media accountability to these two groups of stakeholders is one of the most widely discussed ethical standards in print and online journalism. Many journalism institutions, including the Society of Professional Journalists ${ }^{1}$, the Canadian Association of Journalists ${ }^{2}$, the American Society of Newspaper Editors ${ }^{3}$, the International Federation of Journalists ${ }^{4}$, and Press Council Nepal ${ }^{5}$ have recognized accountability as one of the fundamental standards of professional journalism. Accordingly, in recent years, there have been many studies of online news media accountability, focused primarily on developed countries in North America and Western Europe. These studies concluded that, in these countries, media accountability to public and professional stakeholders tends to increase on digital platforms (Acharya, 2015; Groenhart, 2012; Heikkilä et al., 2012; Joseph, 2011; Lasorsa, Seth, Lewis, and Holton, 2012; Singer, 2005), but some of these studies also acknowledge that the practice of media accountability varies based on newsroom cultures, infrastructural requirements, and a range of external forces (Acharya, 2015; Joseph, 2011; Groenhart, 2012; Heikkilä et al., 2012). Basic factors, such as access to the Internet, media literacy, opportunities for interactivity, and knowledge of media ethics, can significantly impact media accountability, since audiences armed with these instruments can use them to reinforce journalistic norms (Acharya, 2015; Fengler, Eberwein, Lauk, and Leppik-Bork, 2011; Groenhart, 2012; Joseph, 2011).

While these studies present a substantial account of online media accountability in developed countries, they largely fail to account for some of the major accountability challenges faced by developing countries. Nepal is a case in point because it is a country where more than three-fourths of the population does not have access to the Internet ${ }^{6}$ and, as a consequence, audiences are unable to

\footnotetext{
${ }^{1}$ SPJ-Society of Professional Journalists. (2014). SPJ code of ethics. Retrieved from https://bit.ly/1n GWBzP. [Accessed: 22 October 2017]

${ }^{2}$ CAJ-Canadian Association of Journalism. (2011). Ethics guidelines. Retrieved from https://bit.ly/ 2RwPvEr. [Accessed: 13 June 2017]

${ }^{3}$ ASNE-American Society of Newspaper Editors. (1975). Statement of principles. Retrieved from https://bit.ly/2E5P9BS. [Accessed: 27 May 2017]

${ }^{4}$ IFJ-International Federation of Journalists. (1986). Status of journalists and journalism ethics: IFJ principles. Retrieved from https://bit.ly/2QxltPr. [Accessed: 20 June 2017]

${ }^{5}$ PCN-Press Council Nepal. (2016b). Journalist Code of Ethics-2016. Retrieved from https://bit.ly/ 2QyQVNd. [Accessed: 22 January 2017]

${ }^{6}$ Internet Live Stats. (2016). Nepal internet users. Retrieved from https://bit.ly/2QBkKNn. [Accessed: 22 June 2017]; Statista. (2018). Internet penetration rate in Nepal from 2005 to 2016. Retrieved from https://bit.ly/2C0v51a. [Accessed: 29 February 2017]
} 
participate in online activities that would empower them to ensure media accountability online through constant monitoring and interactivity. Nonetheless, hundreds of online news portals are in regular operation. According to the annual reports of Press Council Nepal from the last five years ${ }^{7}$, there have been a significant number of complaints from the general public regarding violations of professional standards and codes of ethics by Nepali journalists and news media, leading to breaches of public accountability. The number of complaints that focus on unprofessional performance by online news media has been increasing every year. In 2013, for instance, $\mathrm{PCN}^{8}$ recorded 63 complaints (including registered 39, suo moto 2, and case referrals 22), whereas, in 2017, the $\mathrm{PCN}^{9}$ recorded 55 complaints against print media, and 65 against electronic media (i.e. radio, television, and online portals). A growing number of complaints have warranted PCN's intervention to apply a code of ethics, and improve professional behaviour among journalists ${ }^{10}$.

Nepal has a diverse media environment that includes more than 800 newspapers, five hundred radio stations, four dozen television channels, 300 online news portals in regular operation, and more than 10,000 people who identify themselves as journalists ${ }^{11}$. In addition, PCN is mandated to develop, as well as update professional standards and codes of ethics for Nepali journalists, in consultation with the Federation of Nepali Journalists (FNJ), to make sure news media in Nepal are responsible to society ${ }^{12}$. However, media scholars and institutions in Nepal (e.g. Acharya, 2005; KC, 2009 ${ }^{13}$ ) note that various unprofessional practices are more dominant in online news portals than in traditional media. Such practices include newsbreaks without proper verification, sensational news presentations, use of secondary sources, the rarity of error correction, and avoidance of critical comments and opinions. This situation is opposite to that described by media scholars from the developed countries (such as Babcock, 2012; Fengler, 2012; Friend and Singer,

\footnotetext{
${ }^{7}$ PCN-Press Council Nepal. (2013). Annual report of press council Nepal. Kathmandu: Press Council Nepal; PCN-Press Council Nepal. (2014). Annual report of press council Nepal. Kathmandu: Press Council Nepal; PCN-Press Council Nepal. (2015). Annual report of press council Nepal. Kathmandu: Press Council Nepal; PCN-Press Council Nepal. (2016a). Annual report of press council Nepal. Kathmandu: Press Council Nepal; PCN-Press Council Nepal. (2017). Annual report of press council nepal. Kathmandu: Press Council Nepal. Retrieved from https://bit.ly/ 2NsS5YW. [Accessed: 2 January 2017]

${ }^{8} \mathrm{PCN}$. (2014). Annual report of press council Nepal, p. 61.

${ }^{9} \mathrm{PCN} .(2017)$. Annual report of press council Nepal, pp. 11, 61.

${ }^{10}$ PCN. (2016b). Journalist Code of Ethics-2016.

${ }^{11}$ FNJ-Federation of Nepali Journalists. (n.d.). Members. Retrieved from https://bit.ly/2RwjfBe. [Accessed: 15 September 2017]; MoIC-Ministry of Information and Communication. (2017). Details of FM radio. Retrieved from https://bit.ly/2PgYV5f. [Accessed: 21 April 2017]

${ }^{12}$ IFAMMN-International Fact-finding and Advocacy Media Mission to Nepal. (2012). Safeguarding media rights and ending impunity in Nepal. Retrieved from https://bit.ly/2zVRjjn. [Accessed: 25 October 2017]; IMMN-International Media Mission to Nepal. (2008). An overview of Nepal's media and recommendations for development priorities: Building for the future. Denmark: International Media Support; Media Foundation Nepal. (2012). Media and Nepali public. Kathmandu: Media Foundation Nepal; Press Council Act. (1992).

${ }^{13}$ IMMN (2008), Unesco (2013).
} 
2007; Heikkilä et al., 2012; Krogh, 2012; Kovach and Rosenstiel, 2014), who hail digital platforms as tools for upholding media accountability. There is not a single law in Nepal that is appropriately mandated to monitor online news portals $^{14}$; the code of ethics for Nepali journalists, which does not effectively cover online media issues with regard to accountability, is widely violated ${ }^{15}$.

Given this context, it is important to identify how, and to what extent, online journalists in Nepal are maintaining professional and public accountability. This research hopes to assist in providing insight into this issue by examining the accountability practices of the top-viewed Nepali online news portals, and it identifies present day trends in the exercise of professional standards in relation to McQuail's (2003) four frames of accountability.

\section{Theoretical Framework}

Over the years, scholars (Bardoel and d'Haenens, 2004; Dennis, Gillmor, and Glasser, 1989; McQuail, 2003) have attempted to concretize the abstract idea of "media accountability to various stakeholders" by introducing frames of accountability for news media. McQuail's four frames (political, market, audience, and professional) of accountability, because of their capacity to assist in analyzing the interest-driven focus of media institutions of specific stakeholders, can be useful tools for analyzing the status of online journalism in Nepal. They are particularly useful with regard to examining media accountability to various stakeholders.

Media accountability in the political frame is maintained through obedience to existing laws and regulations and through punishments for disobedience. Issues such as intellectual property rights, ownership and monopoly, free expression, claims of harm to individuals, and censorship have been discussed under this frame. The political or legal frame refers to "all public policies, laws and regulations that affect media structure and operation" in order to maintain free expression, to advance social betterment, and to limit potential harm (McQuail, 2005, p. 212).

The market frame denotes the system of supply and demand, in which the choices of the public are given free reign, and considerations of efficiency also play a role (McQuail, 2005, p. 213). Accountability to the market is crucial because media outlets' relationships to corporate agencies tend to generate revenues, sponsorship, and financial support. Kovach and Rosenstiel (2014) observe that most media promoters want their newsmakers to foster the former's interests and to be accountable to them, and that many journalists in the US are provided performance bonuses on that basis.

The audience, which includes advocates, media consumer organizations, public welfare councils, and marginalized or minority groups, becomes a part of media accountability. The public frame encourages audiences to interact and

\footnotetext{
${ }^{14}$ IFAMMN. (2012). Safeguarding media rights and ending impunity in Nepal; Media Foundation Nepal. (2012). Media and Nepali public.

${ }^{15} \mathrm{PCN}$. (2015). Annual report of press council Nepal.
} 
participate through direct questions, criticism, and expressions of concern. When a particular media outlet fails to maintain its professional obligations, critical feedback from the public can get the media outlet back on track (McQuail, 2005).

The fourth frame of media accountability is the professional (or selfregulatory) frame, which refers to the maintenance of journalistic autonomy, professional standards, and credibility through conformity to ethical codes and the fostering of public trust (McQuail, 2005). The professional frame strives to "maintain a balance between freedom to publish, the needs of media industries, the wider interests of society, and its constituent individuals and groups" (McQuail, 1997, p. 523). In this frame, journalists develop their own standards for professional excellence and aspire to uphold professional obligations voluntarily.

Scholars of media accountability (such as Bardoel and d'Haenens, 2004; Fengler, 2012; Heikkilä et al., 2012; Hutchins, 1947; Krogh, 2012; McQuail, 2003, 2005) have recommended the self-regulatory and public frames as the primary modalities to be employed in any news media. For them, digital platforms stimulate media accountability and transparency via interactive features that enable audiences to react, interact, engage in dialogue, and collaborate in the newsmaking process. The public and professional frames of media accountability are close and complementary, and the real spirit of socially responsible news media lies in these two frames (McQuail, 2003). Though some features overlap from one frame to another, no frame is perfect and complete, and strengths and weaknesses can be discerned in each frame (McQuail, 2003, 2005). These four frames are chosen as they resemble the imperfect situation of Nepal, citizens of which are seriously affected from the digital divide and low levels of media literacy ${ }^{16}$.

\section{Methodology}

A case study approach with three different data collection methods was used for this research project including: a document review, semi-structured interviews, and an analysis of archival records (Yin, 2009).

The document review was used to assess current accountability practices on digital media platforms and also to compare the data obtained from the interviews. Semi-structured interviews were essential for revealing ideas and perceptions on the research theme. The participants were interviewed about their practical experiences with regard to media accountability on digital platforms using various themes. These themes included, conceptual understanding of media accountability, ethical practices, challenges to maintaining accountability on digital platforms, and the role of audiences in making news media accountable to the general public. Archival records were used for assessing whether or not the interview participants employed accountability indicators consistently.

On a randomly selected date, the researcher identified five of the most-viewed news portals (i.e. onlinekhabar.com, ekantipur.com, nagariknews.com, setopati.

\footnotetext{
${ }^{16}$ Internet Live Stats. (2016). Nepal internet users; Statista. (2018). Internet penetration rate in Nepal from 2005 to 2016.
} 
com, and ujyaaloonline.com) in Nepal using Alexa Internet-web-tracking software that analyzes the ranking of websites. On the same day, the researcher selected five news stories from each portal (for a total of 25) using convenience sampling (beginning from the top of the portals) because of its ease, rapidity, lower cost, and facility for finding readily available participants (Deacon, Murdock, Pickering, and Golding, 2007; Neuman and Robson, 2012). The researcher then contacted the chief (or his subordinate) of the editorial department and a reporter (among the contributors of the selected news reports) from each news portal via email, requesting them to participate in this research. Hence, the researcher selected 10 online journalists to obtain different perspectives on journalism in the field and in the newsroom. The researcher assumed that journalists representing editorial departments could answer specific queries because of their experience and authority. They were asked about the potential influence of different stakeholders during the news gatekeeping process. News reporters were asked about the practical realities of the field. Using the third data collection method (archival record analysis), the researcher collected one news story from each of the five news portals. They needed to be (a) at least six months prior to the data collection date, (b) contributed by interview participants, and (c) archived in the news portal.

First, the researcher analyzed the content of the selected 25 news stories based on the criteria developed (i.e. using clear news source and quotes, publishing readers' feedback on the news, archiving content on the portal's website, providing hyperlinks of related stories, among others), and compared it with external sources. The external sources selected, were among the "A" grade newspapers - as classified by the PCN for their professional performance - that reported on the same issues on similar dates. Second, data obtained from the semistructured interviews were coded and analyzed using a conventional content analysis method. Thematic codes were developed from the available data, patterns were detected, and linkages among the codes were identified in order to analyze the content (Neuman and Robson, 2012). Finally, news stories selected for the archival records were analyzed using the same process used for the document review to assess how consistent the interview participants were with regard to upholding ethical practices on the digital platforms. The interview participants were given codes in place of their real names (and were identified as Participant 1, 2 , or $3 \ldots$ in this article) to protect their identities. They were asked to comment not only about their work experiences, but also about organizational policies that may contradict institutional codes of conduct. Finally, data obtained from these three methods were triangulated to ensure the validity and reliability of the findings, and to reduce potential biases resulting from particular methods of data collection (Baxter and Jack 2008; Yin, 2009).

\section{Findings}

Findings of the three data collection methods are presented as follows: 


\section{Review of the Online-Articles (Document Review)}

When compared to two external sources, more than two-thirds (18) of the 25 news stories assessed as part of the document review were found to be similar in terms of the names, numbers, places, and incidents reported. Eleven of the 25 news stories incorporated quotes of the news source clearly and included direct quotes. Five of the news stories also mentioned news sources, but did not use direct quotes, and a news report used three anonymous sources to support a political rumour. Moreover, only 10 news stories included by-lines, while three others provided institutional credit lines, and the remaining stories did not identify who collected the stories from the field.

Among the 25 news stories, only 11 published audience comments, and most of these comments were short and non-critical. In addition, among the five topviewed sites from which the stories were selected, only ekantipur.com had a briefly stated policy regarding the publication of audience feedback on published stories. It was also found that news stories shared through social media platforms received more comments on social media pages than they did in the original news portals themselves. Social media pages contained more critical comments than the original news portals, which were filled with positive, neutral, or less critical comments.

Scholars believe that information (as well as news stories) archived on the Internet is also an indicator of accountability (Beagrie, 2008; Kovach and Rosenstiel, 2014; Dirks, 2004). Archiving on digital platforms helps audiences find past stories as well as comments about them, and also allows for audiences to file complaints about past stories. When checked after six months of the data collection date, all the news stories were found archived in their respective news portals, though three of them were found in different locations than where they were first made available. However, most of the news portals did not provide links to related, updated, or follow-up stories in the same news portals. Even though the majority of the 25 news stories did not use photos at all, eight news stories used photos without credit. Only two news stories credited photos, as per the guidelines of the Press Council Nepal ${ }^{17}$.

\section{Semi-Structured Interview Content}

Participants were asked nine semi-structured questions covering key themes, including their conceptual understanding of media accountability, the status of accountability of news media on digital platforms in Nepal, the major challenges for ensuring accountability on such media, and the role of audiences in making online news media accountable.

Interview participants expressed optimism regarding the potential for quality journalism in Nepal based on what they saw as strengths (such as the quantitative growth of the news media in Nepal, journalism education programs in various universities, community empowerment through local radios, and online news

\footnotetext{
${ }^{17} \mathrm{PCN}$. (2016b). Journalist Code of Ethics-2016.
} 
portals for connecting Nepali diasporas). In response to a question about the key factors that help ensure media accountable to professional and public stakeholders in Nepal, the majority of study participants attested that journalists' educational backgrounds and individual commitment to the profession are among the most important. For instance, Participant 6 expressed hope that educated and committed journalists in the newsroom would not compromise professional and ethical norms despite pressure from the market or from media owners themselves.

All the interview participants interpreted "media accountability" as the responsibility of media or journalists to society: for instance, media accountability is a form of social responsibility (Participant 3); it follows a code of ethics, international practice, and the law of the land (Participants 1 and 6); it encourages media outlets to take responsibility when there are factual errors (Participant 2); it encourages journalists to present media content in an appropriate manner (Participant 6); and it "is not an individual's responsibility; it is an outcome of teamwork. So, accountability is a shared responsibility in an institutional setting" (Participant 4). Even though participants expressed their inability or confusion when asked to define the term "accountability" in a theoretical way, each participant explained the term with a focus on different aspects of accountability.

Participant 7 believed that the professional performance of journalists should always be guided and monitored by their editorial supervisors. According to her, "if editorial supervisors are fully committed to journalistic values and guide reporters accordingly, the latter will demonstrate professional performance more seriously". In contrast, Participant 6 emphasized the role of the journalist him/herself, saying, "Professionalism begins with the journalists themselves". According to him, journalists should remain committed to journalistic values through their words and deeds; other factors should have only a secondary role.

In response to a query regarding whether or not online media are better than their traditional counterparts with regard to maintaining media accountability, the study participants expressed a variety of perspectives. A majority argued that traditional media outlets are better at maintaining accountability because they have a long history and possess better resources such as an established infrastructure and networks of qualified journalists (Participants 3, 4, 5, 6, 9 and 10). Participant 10 specifically referred to print media as the most accountable and ethical form of news media, particularly the broadsheet daily newspapers with national circulation:

Mainstream daily newspapers seem more ethical than other news media, including online. The reasons behind this can include a decades-long work tradition, a nationwide network of human resources, and large-scale investment. In Nepal, local radio stations came into existence 15 years before, private television channels were introduced around 10 years or more, and online media outlets are newer than any other news media.

The interview participants agreed theoretically on various indicators of media accountability to public and professional stakeholders. However, their everyday practices were different. For instance, despite theoretical emphasis of interview 
participants, complaints from the public were not valued equally and answered well by the newsrooms.

Interview participants found that their media institutions did not handle public complaints properly, but had suggestions on how they could improve. Participant 4 suggested, "In case of the difficult situation of handling complaints from the public, I have to face the public, interact with them, and convince them of the good intentions of the newsroom". Likewise, Participant 8 suggested listening to the audience and being honest:

This is very simple. You have to listen to them with the humility that you might have made a mistake. You have to admit that you cannot be 100 percent accurate in your information, and the news you send cannot be 100 percent true because we do not work in a perfect world. Your editorial team is not perfect, nor is your editor. So, you have to admit everyday that you are liable to make mistakes.

However, a couple of the interview participants indicated that not all complaints that come from the audience are legitimate. Participant 1 said, "We usually do not ignore or delete public complaints unless they are deceitful, obscene, or defamatory, deliberately targeting any person or institution". For his part, Participant 3 pointed out that handling complaints should not undermine journalistic values:

Many people say that audience interest is the principal motive for a working journalist or a particular media house. However, for me, audience interests or complaints should be handled within the scope of journalistic values and the code of ethics. Audiences are not experts on all issues, so they should not be always decisive.

Another unethical trend of several news portals of Nepal is to hide contact details from the audience. According to Participants 5 and 6, a number of smallscaled news portals hid detailed contact information (such as, office addresses, postal codes, telephone/fax numbers, and e-mails) from web pages to avoid criticism and direct confrontation with the public. Participants 1 and 6 argued that this practice makes online journalists non-interactive, and allows for the spreading of unprofessional practices, such as the publication of disputed content and defamatory materials.

Most of the interview participants agreed that responding to audience feedback in an appropriate manner is an indicator of media accountability. Participants 1, 5 and 9 asserted that media organizations have been unfair when responding to or publishing audience comments, despite their feedback-receiving policies. These participants argued that media outlets usually publish supportive or less critical comments and ignore opinions that displease media promoters and advertisers. Participant 6 asked, "Have you ever seen any media criticism against the Chaudhari Group [an industrial group in Nepal]? Of course, not. It is because of advertisements". 
All participants in the study claimed that their respective media organizations had policies (written or unwritten) for receiving and editing feedback in order to foster media accountability. Participants 1, 3, 5, and 7 maintained that media institutions can promote quality journalism by employing a feedback-receiving policy that guides journalists to filter obscene language, defamatory content, and biased allegations before publishing audience feedback. Participant 3 further speculated, "Online media can have more feedback responses because they are interactive and immediate, and they can, therefore, be expected to be more accountable to the public". However, Participant 9 warned that, "In traditional media, audience feedback is in editorial control, but online it is just the opposite". Overall, participants indicated that their media organizations lack specific policies for handling complaints, and noted a trend of avoiding critical feedback in different ways.

Most of the interview participants agreed that all other stakeholders of accountability have a potential influence on media accountability practices, but that the market is the dominant source of influence on media outlets because of sustainability. Participants put forward a number of reasons to support this argument, such as "the market directly benefits media outlets" (Participant 1), "market domination is a global phenomenon"; (Participant 6), and "media owners are more interested in revenue collection than content quality" (Participant 7). Participants 1, 5, and 7 stated that media owners constantly think of potential sources of revenue, and that journalists are thereby bound to compromise professional values to ensure the organization's sustainability. Regarding the interest of media owners, Participant 5 observed:

As a working journalist, if I do not respect the interests of the media owners, I will be immediately kicked out of the job, and the next job is not easily available. Because of this limitation, I am bound to compromise journalistic integrity and ethical values to safeguard owners' interests, as well as market interests.

Moreover, according to Participant 6, advertisements and sponsorships are used as weapons to restrict media criticism. Participant 1 further observed that when news stories are selected or rejected based on market interests, the market frame becomes dominant. Participant 5 maintained, "A corporate institution does not invest a huge sum of money [on media infrastructure and regular operation] just to serve the social responsibility theory of the press, but to make more money". Furthermore, according to participant 7, the market can delay, distort, or even kill news that runs against the interests of market stakeholders, such as advertisers, sponsors, or donors.

A majority of interview participants considered that political stakeholders are the second most dominant stakeholders of accountability, after market stakeholders. Participants 1, 3, 6, 8, and 9 interpreted the concept of political stakeholders (i.e. political parties and their sister institutions) as something different than the legal stakeholders (i.e. existing legal provisions) in Nepal's context. Participant 1 observed that even the existing rules and regulations to be 
followed by news media, including online news portals, have been violated by political stakeholders, resulting in hate speech, defamation, and media propaganda. Participants 7 and 8 contended that political polarization in Nepali media has increased the influence of politics in content selection and presentation. For his part, Participant 10 observed a transition in political influence from traditional media to online media, arguing that "Newspapers were published as political mouthpieces in the past, but today, online news portals have replaced them".

Even though market stakeholders are viewed as the most influential group of media accountability indicators, six of the participants pointed toward the audience as the most important stakeholder of media accountability. These participants presented theoretical reasons to support why they thought online media ought to be more accountable to their audiences. Interview participants, however, stated that this emphasis on accountability to the audience has not been achieved. Focusing on the audience does not directly benefit media outlets compared to focusing on the market and political stakeholders. Four of the study participants asserted that professional and audience accountability stakeholders should be considered together, with professional standards guiding the practice of accountability toward audiences. For instance, Participant 4 observed that the "audience is important", but emphasized that "a professional journalist cannot fulfill audience demands that are in conflict with ethical values". Likewise, Participant 3 stressed that professional accountability should be dominant in all types of media, including online:

The professional frame should prevail over other frames of accountability. For me, other factors have a secondary role only. Those who compromise professional integrity and ethical values cannot be professional journalists. Journalists need to use their conscience and their expertise of journalistic values and the code of ethics to decide what sort of content is socially digestible, and how much can be served for a healthy society.

Hence, a majority of the interview participants thought that traditional media and the news portals associated with them were performing better than online news portals in terms of professional practices and media accountability. Similarly, participants argued that most of the news media outlets, including their online news portals, have been dominated by market interests because sustainability concerns are fundamental.

\section{Archival Records Review}

In order to assess whether or not accountability practices in the selected news portals are consistent with the findings of the aforementioned 25 news stories and the claims by the interview participants, the contents of five news stories (published six months before or earlier from the date of data collection), taken from the archives of the selected news portals, were analyzed, using the same accountability criteria used for the document review method. All news stories were found archived for future reference and no advertisements were found to be 
presented as news stories. However, various issues such as factual errors in the news stories, lack of news source, lack of critical feedback, use of anonymous quotes, and use of photos without credits were noted. Hence, the findings of archival records largely equated and were closely consistent to the findings of the document review, and the observations made by the interview participants with regard to accountability practices of the selected news portals.

In this section, data obtained from the three different methods were presented. The findings from each method were consistent with one another. Several issues relating to unethical practices of news media and journalists were not only identified in the selected news stories, but also revealed through practice, as a majority of the interview participants admitted to their existence. The patterns of the findings obtained through the triangulation of the data are discussed in the next section.

\section{Discussion and Conclusion}

For over a decade, there has been an ongoing debate among scholars about whether or not media on digital platforms are more credible and accountable than traditional media like television and newspapers. Scholars such as Kovach and Rosenstiel (2014) and Friend and Singer (2007) argue that online media can afford to be more accountable because digital platforms have unique capabilities, such as interactivity and transparency through hyperlinks. However, some scholars, such as El Semary and Al Khaja (2013), contend that traditional media are better than online media because "the credibility of traditional journalism stems from experience of highly skilled correspondents and editors as well as the depth of news coverage offered through analyses on the events" (p. 53).

A majority of the participants in this study remarked that online news portals in Nepal are performing less adequately than their traditional counterparts in maintaining accountability towards the public. Similarly, these participants perceived that associated online media (news portals parented by traditional media) were performing better than online-only news portals with regard to public and professional stakeholders of media accountability. They argued that associated online portals could benefit from the available resources (such as infrastructure, a wide network of journalists, and systematic gatekeeping mechanisms) and the continuous professional practices of traditional media.

However, there are always risk factors with both types of news portals. For instance, associated online news portals may merely "shovel" (or reproduce) traditional media content onto digital platforms, and the online-only news portals (i.e. onlinekhabar.com and setopati.com) may depend heavily on secondary sources for a significant portion of their news content. Moreover, most of the interview participants believed that particular media platforms themselves are not adequate to uphold media accountability to public and professional stakeholders, and that resource availability, as well as the professional commitments of journalists and media leadership can make any media (traditional or online) accountable to public and professional stakeholders. This is consistent with the 
argument made by Kovach and Rosenstiel (2014) who maintain that regardless of the medium, journalists and media institutions must demonstrate their primary loyalty to citizens.

Regarding complaint handling strategies in online news portals, interview participants suggested different steps for journalists and media organizations to follow when handling public complaints: (a) journalists or media organizations should listen to audiences or the concerned public in order to understand the issue, (b) journalists should acknowledge errors quickly and admit mistakes publicly, (c) information should be updated transparently as soon as possible, and (d) media outlets should provide a place where audiences can express their concerns. The substance of these complaint-handling steps has already been included in the journalistic codes of ethics prepared by different professional organizations such as $\mathrm{CAJ}^{18}, \mathrm{PCN}^{19}$ and $\mathrm{SPJ}^{20}$. Interview participants suggested that when such steps are not followed properly, a third party, such as a press council or ombudsman should get involved in order to settle public complaints.

This research study found that there are several obstacles for online news portals in Nepal to properly handle complaints. For instance, many Nepali news portals, according to the interview participants, were found withholding detailed contact information or only providing a feedback receiving template to audience members in order to shield themselves from legal or social challenges resulting from the news reporting. Hence, when media portals use such one-way communication tools, audiences cannot enjoy interactivity, expect responsible replies to their complaints, participate in the news making process, or make online media accountable, despite the non-traditional features of the digital platform (such as global accessibility, transparency through hyperlinks, and interactivity). The trend of withholding contact information on digital platforms is not only in Nepal nor is it unique to developed countries. In North America, most news outlets provide feedback forms or general newsroom numbers rather than making specific journalist information available (see for example: Canadian Broadcast Corporation's (CBC) official website for commenting on news or contacting journalists $^{21}$.

This research study also found that comments from audience members about news stories are often removed on various grounds such as obscenity, defamation, deliberate criticism or bias. This is just another unprofessional trend that impedes accountability on digital platforms. The researcher suspects this finding to be linked to news media on digital platforms voluntarily choosing not to adopt the aforementioned unique features to uphold accountability, but rather participating in face saving activities through post-deletion or content removal. This is not all that different than practices found in other parts of the world. In Canada, for example, the national public broadcaster sometimes prevents online readers' from

\footnotetext{
${ }^{18}$ CAJ. (2011). Ethics guidelines.

${ }^{19}$ PCN. (2016b). Journalist Code of Ethics-2016.

${ }^{20}$ SPJ. (2014). SPJ code of ethics.

${ }^{21}$ CBC Policies. (2017). CBC/radio-Canada content submission guidelines for CBC/radio-Canada owned or controlled platforms. Retrieved from https://bit.ly/2E5bYG5. [Accessed: 27 September 2017]
} 
commenting on news stories they feel are controversial. A story entitled "3 UK schoolgirls suspected of joining ISIS in Syria", published on February 21, 2015, was closed within 24 hours on the $C B C$ 's official website ${ }^{22}$.

Market domination or substantial influence of market on media content is a global tendency (McQuail, 2003), and Nepal is no exception. However, because of market domination, corporate media with large-scale investments (such as television channels, national or regional radio stations, and broadsheet daily newspapers) are highly loyal to market interests in order to maintain regular operating costs and, hopefully, generate profits (Kovach and Rosenstiel, 2014). McQuail (2003) explains that a variety of issues, such as profitability, competition, technological development, and quality of service, may influence media to be accountable to the market. Five of the interview participants of this study argued that the major focus of media owners in Nepal is profitability, and that, as a consequence, the quality of media content may be compromised. Moreover, participants also found that advertisement and sponsorship of content are occasionally employed as preventive measures to curb media criticism from market actors.

Some media scholars argue that advertising has a significant influence in North America and Europe. Bob Franklin (2005) argues that news media most often prepare news agendas to strategically target a particular segment of the audience for advertisers. For him, "a relationship between a niche publisher and advertisers can be so financially symbiotic that self-censorship is likely to dilute journalistic principles" (Franklin, 2005, p. 9). Similarly, Kovach and Rosenstiel (2014) refer to an example of the Times Mirror Company, whose management promoted market interests without letting the newsroom know.

After market influence, political influence is observed as the most pervasive in the selected online news portals, as well as in Nepali media in general, due to political polarization among journalists and the increased influence of politics in content selection. Major political parties have their own media, or media under their influence, in order to support their actions or promote favourable propaganda $^{23}$. Similarly, the Government of Nepal operates a number of media outlets, which tend to be loyal to the ruling powers and remain subject to extensive

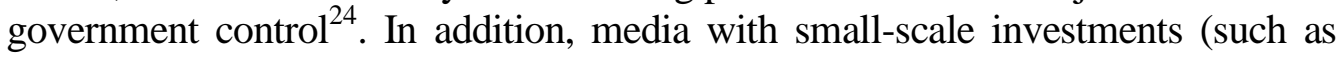
weekly newspapers and online-only news portals) are, as some interview participants observed, more influenced by partisan interests because the market seldom trusts them, and they need financial support from a variety of sources in order to be sustainable.

As many scholars (such as Kovach and Rosenstiel, 2014; McQuail, 2005) emphasized the role of audiences in making news media accountable to public and professional self-regulation, journalists participating in this research also prioritized the audiences as the main stakeholders. According to these participants,

\footnotetext{
${ }^{22}$ CBC News. (2015, February 21). 3 UK schoolgirls suspected of joining ISIS in Syria. Retrieved from https://bit.ly/2QzjqdU. [Accessed: 27 September 2017]

${ }^{23}$ UNESCO. (2013). Assessment of media development in Nepal.

${ }^{24}$ IMMN. (2008). An overview of Nepal's media and recommendations for development priorities: Building for the future; Media Foundation Nepal. (2012). Media and Nepali public.
} 
audience's feedback on news and features, and their involvement in contributing relevant information to the news-making process are important in order to improve the quality of news content. Since the restoration of multi-party democracy in Nepal (i.e. 1990), the social responsibility theory of news media has always been a matter of public discussion from the street to parliament ${ }^{25}$. For instance, the code of journalistic ethics for Nepali journalists has clearly mentioned the responsibility and accountability of journalists and media institutions to the public. According to interview participants, audiences, however, were mostly ignored or strategically sidelined when audiences commented against the interests of media institutions, sponsors and journalists.

Among the four frames of accountability discussed by media scholars (such as Bardoel and d'Haenens, 2004; McQuail, 2003, 2005), interview participants emphasized the importance of audience frame to make online news portals accountable to the general public. The market frame, however, dominates media accountability in the selected news portals for this study in practical terms because media owners, according to the most of the interview participants, are interested in covering operational costs and making profits. Interview participants argued that small-scale media (such as online-only news portals) largely depend on political sources to seek financial supports because the market has not trusted them as reliable media for advertising their services and products. There is a noticeable gap between the theory and everyday practice of journalism in making journalists and media accountable to the general public. Such a gap can be eliminated or narrowed, as argued by the interview participants, when journalists and media promoters are educated and trained in journalistic values and ethics that encourage media and journalists to be accountable to the public.

Furthermore, the findings suggest that a modification to the theoretical frame of media accountability would be warranted to clearly analyze the different scenarios of political and legal accountability. The frame synonymously uses "political" and "legal" terms to denote the legislative obligations of media institutions and journalists. Scholars, such as Bardoel and d'Haenens (2004), Krogh (2012), McQuail (2003) state that all public policies, laws, and regulations related to media are within the political (or legal) frame, and the implementation of the frame can be coercive, confrontational, and non-negotiable. However, this theoretical frame fails to assume the realities of a developing country like Nepal where legal and political scenarios are considerably different. On the one hand, there are constitutional and legal provisions to regulate news media, which can be equally applied to all media institutions and journalists ${ }^{26}$. On the other hand, there is a strong political hold on media and journalists, such as government controlled state-funded media (such as Gorkhapatra, Radio Nepal, Nepal Television, and National News Agency), political parties directly or indirectly run media outlets

\footnotetext{
${ }^{25}$ IFAMMN. (2012). Safeguarding media rights and ending impunity in Nepal; Media Foundation Nepal. (2012). Media and Nepali public; UNESCO. (2013). Assessment of media development in Nepal.

${ }^{26}$ IFAMMN. (2012). Safeguarding media rights and ending impunity in Nepal; IMMN. (2008). An overview of Nepal's media and recommendations for development priorities: Building for the future; UNESCO. (2013). Assessment of media development in Nepal.
} 
(from print to online) to promote partisan interests, and most of the journalists and media institutions in Nepal have been polarized into different political parties. Consequently, these media and journalists can be more accountable to political institutions and promote partisan interests in the hope of getting political opportunities. Therefore, the media accountability frame can be modified and expanded into five different stakeholder groups: legal, political, market, professional, and public, so that the media accountability scenario in a developing country can be better interpreted.

Contrasting to the findings of Western studies that media and journalists are likely to be more accountable to the general public on digital platforms (McQuail, 2003; Kovach and Rosenstiel, 2014; Friend and Singer, 2007), this research study finds that online news portals in Nepal are less accountable to their professional and public stakeholders. Further research is warranted to assess the status of media accountability on digital platforms in other developing countries to determine if the same factors may be applied and to determine to what extent developing countries differ each other's media environment.

\section{Acknowledgement}

The author would like to thank Prof. Genevieve Bonin, University of Ottawa, for her guidance as a supervisor of this research project.

\section{References}

Acharya, B. B. (2015). Media accountability on digital platforms: The role of audience. Amity Journal of Media \& Communications Studies (AJMCS), 5.

Acharya, U. (2005). Online media ethics: A study of issues of ethical standard of Nepal's online media. Kathmandu: Centre for Media Research Nepal.

Babcock, W. (Ed.). (2012). Media accountability: Who will watch the watchdog in the Twitter age? New York: Routledge.

Bardoel, J., and d'Haenens, L. (2004). Media responsibility and accountability: New conceptualizations and practices. Communications, 29(1), 5-25.

Baxter, P., and Jack, S. (2008). Qualitative case study methodology: Study design and implementation for novice researchers. The Qualitative Report, 13(4), 544-559.

Beagrie, N. (2008). Digital curation for science, digital libraries, and individuals. International Journal of Digital Curation, 1(1), 3-16.

Deacon, D., Murdock, G., Pickering, M., and Golding, P. (2007). Researching communications: A practical guide to methods in media and cultural analysis. London: Hodder Arnold.

Dennis, E. E., Gillmor, D. M., and Glasser, T. L. (Ed.). (1989). Media freedom and accountability. New York: Greenwood Press.

Deuze, M. and Yeshua, D. (2001). Online journalists face new ethical dilemmas: Lessons from the Netherlands. Journal of Mass Media Ethics, 16(4), 273-292.

Dirks, J. M. (2004). Accountability, History, and archives: Conflicting priorities or synthesized strands? Archivaria, 1(57), 29-49. 
El Semary, H., and Al Khaja, M. (2013). The credibility of citizen journalism and traditional TV journalism among Emirati youth: Comparative study. American International Journal of Contemporary Research, 3(11), 53-62.

Fengler, S. (2012). From media self-regulation to "crowd-criticism": Media accountability in the digital age. Central European Journal of Communication, 9, 175-189.

Fengler, S., Eberwein, T. Lauk, E. and Leppik-Bork, T. (2011). Mapping media accountability - in Europe and beyond. In T. Eberwein, S. Fengler, and E. Lauk (Eds.), Mapping Media Accountability-in Europe and Beyond (pp. 7-21). Köln, Germany: Herbert von Halem Verlag.

Franklin, B. (Ed.). (2005). Key concepts in journalism studies. London: Sage.

Friend, C., and Singer, J. B. (2007). Online journalism ethics: Traditions and transitions. New York: ME Sharpe.

Groenhart, H. (2012). Users' perception of media accountability. Central European Journal of Communication, 9, 190-203.

Heikkilä, H., Domingo, D., Pies, J., Glowacki, M., Kus, M., and Baisnée, O. (2012). Media accountability goes online: A transnational study on emerging practices and innovations. Retrieved from https://bit.ly/2NrnCu1. [Accessed: 20 September 2017]

Hutchins, R. M. (1947). A free and responsible press: A general report on mass communication: Newspapers, Radio, Motion Pictures, Magazines. Chicago: The University of Chicago Press.

Joseph, N. L. (2011). Correcting the record: The impact of the digital news age on the performance of press accountability. Journalism Practice, 5(6), 704-718.

KC, B. (2009). Practice of journalistic ethics in Nepal. In B. KC. (Eds.), MBM anthology of media ethics (pp. 7-24). Kathmandu: Madan Bhandari Memorial College.

Kovach, B., and Rosenstiel, T. (2014). The elements of journalism: What newspeople should know and the public should expect. New York: Three Rivers Press.

Krogh, T. V. (2012). Understanding media accountability: Media accountability in relation to media criticism and media governance in Sweden 1940-2010. (Unpublished doctoral dissertation). Mid Sweden University, Sweden.

Lasorsa, D., Seth, L., Lewis, C., and Holton, A. E. (2012). Normalizing Twitter: Journalism practice in an emerging communication space. Journalism Studies, 13(1), 19-36.

McQuail, D. (1997). Accountability of media to society principles and means. European Journal of Communication, 12(4), 511-529.

McQuail, D. (2003). Media accountability and freedom of publication. Oxford: Oxford University Press.

McQuail, D. (2005). McQuail's mass communication theory. New Delhi: Vistaar Publications.

Neuman, W. L., and Robson, K. (2012). Basics of social research: Qualitative and quantitative approaches (2nd Canadian Ed.). Toronto: Pearson Canada.

Plaisance, P. L. (2000). The concept of media accountability reconsidered. Journal of Mass Media Ethics, 15(4), 257-268.

Singer, J. B. (2005). The political j-blogger "normalizing" a new media form to fit old norms and practices. Journalism, 6(2), 173-198.

Ward, S. J. A. (2010). Global journalism ethics. Montreal: McGill-Queen's Press.

Yin, R. K. (2009). Case study research: Design and methods. Thousand Oaks: Sage. 



\title{
Pattern while Watching $360^{\circ}$ Videos. On the Reception of Immersive Commercials
}

\author{
By Andreas Hebbel-Seeger ${ }^{*} \&$ Andes Diesch ${ }^{*}$
}

$360^{\circ}$ videos allow the recipient to freely select a section of an image within a spherical spatial construction. In the presented study we will analyze two chosen $360^{\circ}$ spots from the automotive industry of the brands BMW and VW initially regarding their $360^{\circ}$ "storytelling" side. In the next step we will depict the reception behavior of the subject group according to their head movements, compare these to each storytelling approach and finally discuss them regarding the background of the reception experience.

Keywords: storytelling, immersive media, 360 degrees video, lean forward commercials.

\section{Introduction}

By now, it is no longer a futuristic vision to lay on the homey couch and, at the same time, dive with sharks, visit the Coliseum in Rome, ride rollercoasters or to take on the role of the hero in video games or movies. It has become reality; virtual reality. Meanwhile, by using their own smartphone, anyone can experience the revolution of media consumption at home and immerse into the world of $360^{\circ}$ videos, with help from a simple head-mounted-display (e.g. Google's Cardboard). Because of the increasing growth of user-friendly $360^{\circ}$ camera systems on the consumer market and the technological integration of corresponding content on social media platforms such as Facebook or YouTube, the popularity and spread of these videos grow from day to day. The immersive potential of this technology promotes a special experience of presence (Singer \& Witmer, 1998, p. 225) that allows the user to "dive into" the visualized world and lets them become a part of the story line (Hebbel-Seeger, 2017).

In advertising contexts, new communicational qualities are established when the recipients are surrounded by the molded brand- and product worlds (Gocht, 2016). But "Storytelling" like within "classic" audio-visual video formats no longer works with immersive videos. The attention of the users can no longer be guided by focal lengths, perspectives and cuts in the sense of a story. The narration of a story works here only indirectly via cues or is completely transferred to the user when "stories" only manifest individually in the mind of the users: "The frame has two very important purposes, which first one is to separate what is visible in the storytelling from what is not visible and where lays the imagination of the spectator" (Lescop, 2017, p. 254).

Since an explicit user guidance in $360^{\circ}$ videos is not possible due to the user's free choice of selecting an image section, a new type of "storytelling" is needed (Díaz-Kommonen et al., 2018), leading the recipient through a specific room

${ }^{*}$ Professor of Media Management, Local Head of Media School, Macromedia University, Germany.

${ }^{\dagger}$ Alumnus, Macromedia University, Germany. 
design and providing information incentives. Hence, one can impart between the possibilities of the medium, individual experiences, interests of the recipients and the intended communicational goal of the advertisement.

The sketched concepts of a storytelling within $360^{\circ}$ videos about cues on the one hand side and an individual story formation on the other hand's side are examined in the present article. By the example of two selected commercials we investigate the gaze directions and head movements of probands to look for specific patterns

\section{$360^{\circ}$ Video}

$360^{\circ}$ videos are cinematic portrayals of reality in which the surroundings are equally captured on every level.

"The mapping of a space in all directions characterizes $360^{\circ}$ photos and videos. Proceeding from a chosen point, namely the position of the camera, a specific occurrence is depicted in its spatial complexity" (Hebbel-Seeger, 2018, p. 273, translated from German into English).

In a spherical projection of these contents the viewer finds himself in the center of this projection. In the course of the process unfolding itself, every viewer can freely choose which extract of the projection to explore. Meanwhile, it is neither possible to affect the plot, nor to change the camera position or to interact with the objects in the depicted area.

$360^{\circ}$ videos are captured with "spherical-, $360^{\circ}-"$, or omnidirectional cameras, which depict a space in every direction with their two or more wide-angle lenses. In contrast to a "classic" video format, there is no "behind-the-lens" in a $360^{\circ}$ video. Everything is recorded at all times and the users alone decide, which extract they want to choose, using either the computer-mouse, the keyboard or a headmounted-display ("VR-glasses"). Especially in combination with VR-Glasses the immersive potential is higher in $360^{\circ}$ videos (Slater \& Wilbur, 1997), as at least two senses (hearing and seeing) are usually affected here, which broadly shields the recipient from the outside world. An appropriate media quality provided, the best requirements for a presence experience are given; the feeling of "actually" being in a place that illustrates a storyline in an audio-visual manner (Singer \& Witmer, 1998; Dörner \& Steinicke, 2013, p. 33ff).

\section{Storytelling}

"In 360-degree videos, similar to traditional storytelling, the viewer does not influence the plot (Vosmeer \& Schouten, 2014, pp. 141-142); the interaction with characters is fixed, and the viewer has no control over anything but their gaze. However, unlike VR where player's actions form the story, the illusion of movement cannot influence the story development (Miller, 2013, p. 120). Thus, interactivity within this medium is only an illusion" (Elmezeny, Edenhofer \& Wimmer, 2018, p. 9). 
In a promotional context, the term "storytelling" is understood as the communication of an advertising message in a narrative frame. This embedding follows mechanisms of narratives that function regardless of whether a story is told at a campsite or within a digital space (Herbst, 2008).

When storytelling is defined in digital media, the term "digital storytelling" acts as a differentiation (Herbst \& Musiolik, 2016, p. 7); the distinctiveness of digital storytelling mainly lies in two central approaches that determine how a story is aligned and how it can be told: the linear approach and the nonlinear approach (Herbst \& Musiolik, 2016, p. 80ff):

a) Linearity: The linearly conceived story describes a story with a clearly defined "path" which the viewer can follow. Thus, the story is constructed in such a way that a foreseeable action can be followed clearly from the beginning to the end.

b) Non-linearity: In a non-linear concept the "path of the story" unfolds differently. The viewers have the same starting point with the beginning of the story, yet it is not predefined, which path the audience will follow subsequently. Through "cross references", the recipient is able to influence the course of the story. Based on the reception of $360^{\circ}$ content, the viewer can choose, for example, what he wants to look at.

\section{Storytelling in $360^{\circ}$ Videos}

Telling a story and conveying a message are goal-oriented processes. Therefore, our guiding question was, whether and how the user's behavior demonstrates storytelling through a $360^{\circ}$ video, and if there are any interindividual reception patterns, although or even because the users have the free choice of choosing an image section.

We decided on using two $360^{\circ}$ commercials from the automotive industry as research objectives, one of them being based on the linear concept and the other on a nonlinear concept. The commercials concerned are taken from the launch campaigns of the automobile manufacturer BMW ${ }^{27}$ (new model "M2") and $\mathrm{VW}^{28}$ (up!-special edition "beats") (Figure 1).

In April, 2016 the German automobile manufacturer BMW launched a new sports wagon: the BMW M2 Coupé, the sports version of the 2er BMW, which achieves about 370 PS. Due to the size, the limousine can be categorized as part of the compact class (Götze, 2016). The market entry of the M2 was communicated through a global launch campaign, involving the model Gigi Hadid and the new sports wagon. The centerpiece of the predominantly digital campaign is a commercial, in which the model enters in one of five M2-Coupés, all of which then drive through the Nevada desert in a "speedy" choreography and perform a type of "cap game" (Theobald, 2016). The $360^{\circ}$ spot was conceptualized by the regular agencies of the automobile manufacturer, Serviceplan (Munich) and KBS

\footnotetext{
${ }^{27}$ https://youtu.be/nlB3Zsr-heE.

${ }^{28} \mathrm{https}: / /$ youtu.be/1rL5vT1sCFo.
} 
(New York). Aside from TV (two-dimensional adaptation), the expansion of the commercials mainly took place in the digital field. Client and agency relied on the media coverage of the testimonial, Gigi Hadid, to spread the advertisement, who currently has 4.2 million likes of Facebook ${ }^{29}$ and 37.1 million followers on Instagram $^{30}$. The selection of the testimonial was Gigi Hadid as her circle of fans corresponds with the target group that BMW wants to approach with communication on the M2 (Theobald, 2016). In general, the commercial can only be described in a minimized way, since it is composed of a few prominent elements only. The most distinctive elements will be described and shown in a timeline in the following.

Figure 1. Screenshots Taken from the Mentioned $360^{\circ}$ Commercials from BMW (Left) and VW (Right)

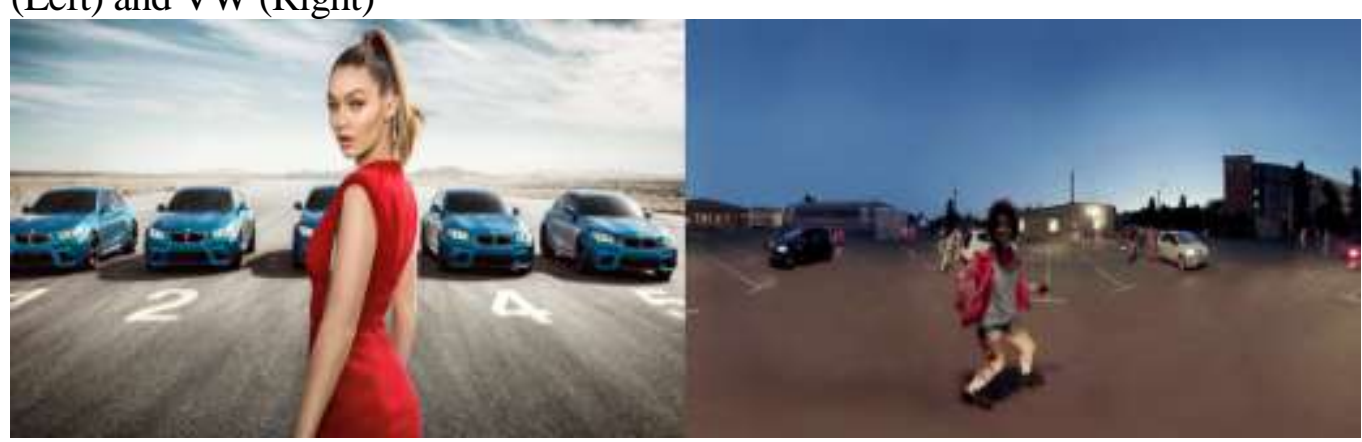

\section{$360^{\circ}$ Commercial from BMW}

Room. The main idea behind $360^{\circ}$ videos and VR is to transport the user into a new world; into a new space. In order to implement this as effectively as possible, the BMW-Spot used a space that can hardly be surpassed in terms of spaciousness: the desert. Incentives used over the course of the plot encourage the recipients to view certain image excerpts instead of a free exploration of space; in this case, those excerpts in which the testimonial moves and cars drive around. In the previous part of this paper, continuity was mentioned as an important part of storytelling. One of the ways in which this element is implemented in the BMW spot is that only one location used in the plot.

Story. The storytelling within the ad follows a linear approach: at the beginning of the spot, the testimonial gets into one of three parked cars in the desert and the viewer is asked to keep his eyes locked on the vehicle in which the model is sitting. Afterwards, the three cars race away and two more vehicles are added. All five vehicles look identical. A "cap game" begins as the cars constantly change positions and formations. At the end of the commercial, the action slows down and all cars come to a stop on the road in a row. Numbers from 1 to 5 show up on front of the cars and the viewer is asked to take a guess in which car the testimonial is sitting on the microsite "EyesOnGigi. com". The story is "classically" divided into three phases: Introduction, main part, end. The story line of the spot is

\footnotetext{
${ }^{29}$ https://www.facebook.com/officialgigihadid/.

${ }^{30}$ https://www.instagram.com/gigihadid/.
} 
heavily reduced from the beginning to only a few distractions. The question "Can you keep your eyes on Gigi?" that is posed at the beginning of the spot makes the purpose unmistakably clear: The viewer is supposed to follow the testimonial, no matter what happens. After the testimonial enters one of the vehicles, it becomes obvious that this task is not so easy: anyone who wants to keep an eye on the testimonial has to remain highly focused while facing all distractions caused by crossing vehicles and order-changing maneuvers. Thereby, the attention of the spectators continuously lies on the vehicles. The entire story follows a pattern that the viewer intuitively understands within the first few seconds.

Cues. With its reduction to the essentials, the BMW spot makes use of fewer cues, meaning fewer things that attract the attention of viewers: no more than five vehicles, the testimonial and the road are visible in the spot. Hence, there is little to distract the viewers' attention. This spot also uses various means to direct the attention of viewers. For example, the testimonial is wearing a dress in deep red, a signal color. The vehicles are painted in dark colors, which poses a strong contrast to the surroundings (relatively colorless) and the protagonist in red.

Further components. For the further control of attentiveness, engine noises are used already in the first few seconds of the spot and thus underline the dynamics of the action. As acceleration increases, the intensity of engine noise deepens and the squeaking of the tires can be heard, underlining the speedy design of the spot and the dynamic driving maneuvers. At the beginning of the spot, viewers are introduced to the scenery through text and language. They are told what this is about. The text and the linguistic invitation to follow the testimonial are intended to direct the recipients' attention without restricting the feeling of potential freedom of movement.

In the following, the term milestone will be used to explain the structure of the spot in more detail. Milestone describes important action points in the spot. These are elements that stand out from the rest of the action by their importance and/or their dramatic significance. With the help of various milestones, this spot pinpoints the attention of viewers repeatedly. These milestones are, for example, the four formations that the vehicles occupy during the "cap game" (Figure 2).

Figure 2. Visualization of the Story Line of the Selected $360^{\circ}$ Advertising Spot from BMW

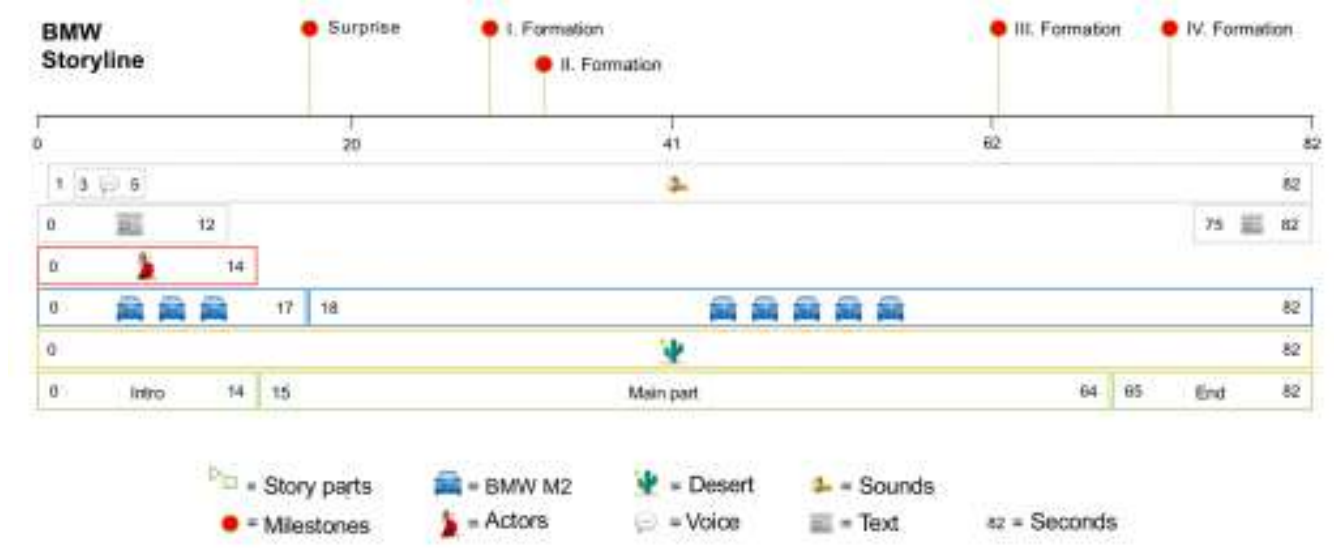




\section{$360^{\circ}$ Spot by VW}

With the "Always right in the middle of it" (German: "Immer mittendrin") campaign, Volkswagen is promoting a new special model of the up! series: the smallest car from the German manufacturer, the "up! Beats". This model is a special edition of the already existing up!, whereas the integrated sound system of Beats-Audio serves as the distinctive characteristic. The feature of the built-in premium music system is intended to attract young buyers in particular. Part of the campaign, that was designed by the Hamburg-based agency Grabarz \& Partner and was mainly developed for print and TV media, is the $360^{\circ}$ spot which is analyzed in this thesis. In addition to the new audio system, more features are meant to be advertised that enable a coupling between smartphone and car. This coupling primarily expands the multimedia range offered by the car (Schobelt, 2016).

Room. The space depicted in the video is divided into three locations: the entrance area in front of a discotheque, the somewhat further away parking lot of the same disco and, at the end of the spot, a black room with several VW logos. Within the spot there are four up! that encircle the viewer. About 40 people dance around these vehicles and form a visual boundary of space.

Story. At the beginning of the spot, the viewer is situated in front of a discotheque and their gaze is aimed at the entrance due to the preset viewing direction in the video. About twelve people are standing in front of the nightclub talking while quiet music is playing in the background. Suddenly, a female person approaches the camera and starts to dance. In the same moment, three vehicles appear opposite of her (three are clearly visible, in the next scene there are four). After about seven seconds, the first camera cut takes place and the location shifts from the setting of the entrance to a large parking area within the range of vision of the discotheque. The woman is still visible in front of the camera and behind her, there are now four VW up! parked in a circle. Most of the dancers are wearing roller skates, letting their movements appear very dynamic but also causing a lot of confusion. The aforementioned woman comes along and moves towards the camera again, interacting with other dancers. After 44 seconds, the dancing scene is over and fades into a black picture with several VW logos while the music continues to play. The spot was developed according to the approach of nonlinearity, whereas this concept is not brought into play by using the content of different spots, but only within this one $360^{\circ}$ video.

Cues. The actress who is approaching the camera at the beginning, functions as a hint, but only initially so. Later on, she does not stand out from the crowd of dancers strongly enough to attract the attention of the audience. In addition, the four cars encircling the spectators are spread out in the parking lot, serving as a cue.

Further components. Similar to the BMW Spot, the VW video works with acoustics: In order to draw attention to the products, the cars are cheered on by the crowd. Calls, whistles and gestures signal the viewer that a decisive action is happening. The honking of the cars also serves to promote the direction of vision. Along with the first camera cutting in this spot, a change of location occurs and the 
spectator now finds himself in the middle of the dancers. Aligning with the technical cut, the music builds up and becomes louder. Afterwards, the main actress and the other protagonists dance around the camera (and thus around the recipient) and between the cars. The second and last cutting is followed by a black room with several Volkswagen logos. These logos are all designed in an identical manner and placed around the camera. Once again, it does not matter which one of the logos the viewer looks at. The placement of several logos suggests that the producer's intention is as follows: Since it is impossible to predict which part of the room the viewer is at the end of the video, logos must be placed everywhere so that they cannot be overlooked.

\section{Comparison of Storylines}

The storyline describes what happens when, where, and how things are related to each other. For the visualization of the storyline we decided to use a timeline. Figures 2 and 3 demonstrate at which point in time which cue appears and disappears in the respective spots. The representation serves to visualize the interaction of individual components and to emphasize their continuity. For the marking of the components, different colored bars are used. Additionally, the most important milestones in the plot are marked by red-green markings on the timeline.

In the BMW Sport, the recipients are being guided at the beginning as the concept of the story is conveyed. At the end, a call-to-action follows. During the spot, the viewer is "left alone" and his or her attention is directed only by the plot (Figure 2, "milestones"). The location and presence of the cars with the smooth transition from three to five cars are clearly visible in their continuity. This ensures a structured process that enables the audience to be guided and orientated in space.

On the other hand, much more is "happening" in the Volkswagen spot. There are three places of action and four vehicles, which are staged by about 40 dancers. Music is playing, the actors are celebrating in front of a disco, the audience is in the center of the cheering crowd and is invited to join in by gestures.

Figure 3. Visualization of the Story Line of the Selected $360^{\circ}$ Advertising Spot by VW

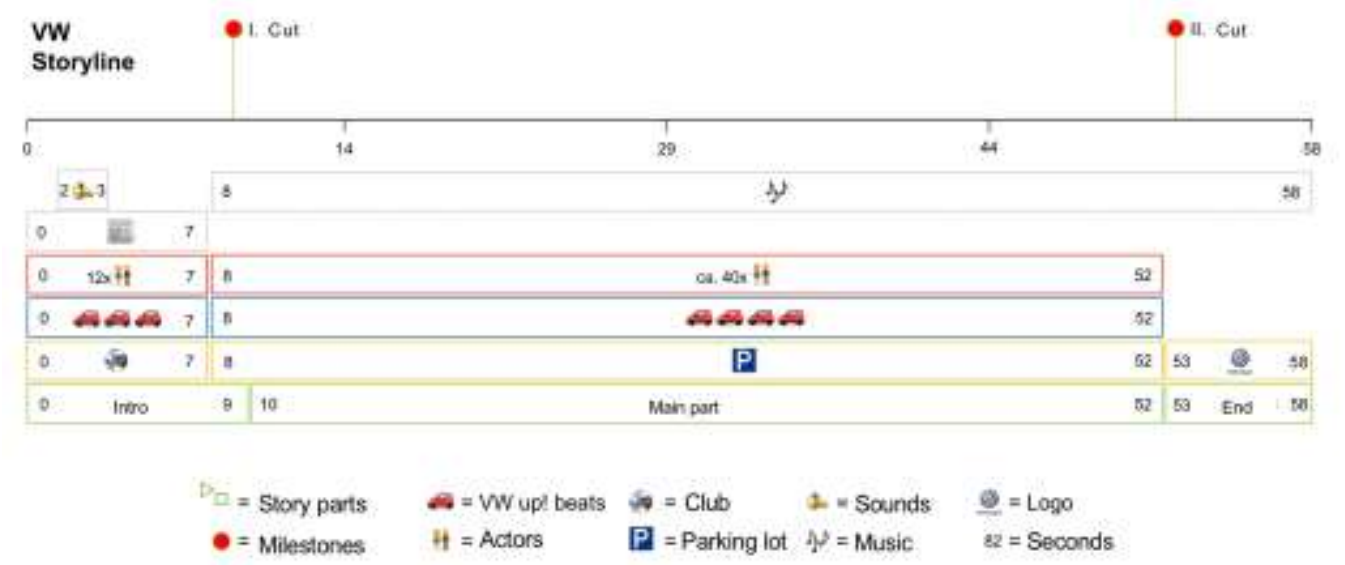


Volkswagen is all about partying, friends and fun, being there in an intoxicating and colorful dynamic lifestyle. Attention should be paid to the party and the audience should be "right there". The up! is the faithful companion, but not the center of attention. What really matters is people having fun with friends.

BMW, on the other hand, is all about the vehicles: performance, sportiness, speed and controlled driving. It is focused on the essentials: Performance and design. The vehicles are the center of the action - nothing is to distract from them. To ensure that this message reaches the audience, a testimonial is used in combination with the provocative invitation to follow along.

The differences outlined between the two selected $360^{\circ}$ advertising spots are based on different framework conditions and communication goals. One spot is a new product introduction (BMW M2) and the other one is an adaption of an already known model (VW up!). As a result, the focus of attention in the first video is mainly on the (new) vehicle, while in the second spot, the attention is to radiate from performance action onto the product, so that the focus is less on the car and more on the surroundings.

\section{Reception of the Selected $360^{\circ}$ Commercials}

The selected $360^{\circ}$ advertising spots focus on two vehicle models that can be assigned to a rather younger clientele due to price, design, communication and image (Volkswagen Media Services, 2016; Theobald, 2016). These are two cars of the compact class, the BMW M2 and the Volkswagen up!, which embody a fresh and youthful image. This may be one of the reasons why the models are advertised, among other things, via the $360^{\circ}$ video, as this media format enjoys a high level of acceptance within the target group (GfK, 2015, cited by Scholz, 2016).

In the context of this study, we have investigated the reception behavior of subjects consuming both $360^{\circ}$ advertising videos. The guiding question in our research was, whether inter-individual patterns can be identified in the reception of $360^{\circ}$ videos, despite the freedom of choice in selecting the image section, and if and in what context these patterns of reception are related to the storyline.

Considering the research question, we were primarily concerned with capturing the head movements through which the individual selection of an image section in a $360^{\circ}$ video is made. In order to record the head and body movements of the test persons, a 3-axis sensor system was added to the VR glasses (Samsung "VR-Gear") mounted on a smartphone (Samsung "Galaxi S7"): Another smartphone with a corresponding recording function (we used the "Sensor Kinetics Pro" app) was placed above the patient's head and connected to the VR glasses by means of a self-constructed holder (Figure 4).

When developing the holder, it was of utmost importance that the sensors were located in the middle of the head and thus at the point of rotation. Since a $360^{\circ}$ rotation with a simple graph cannot be displayed, the measured values were put out in $0^{\circ}$ to $90^{\circ}$ and $180^{\circ}$, as well as $0^{\circ}$ to $-90^{\circ}$ and $-180^{\circ}$ by the app. Figure 5 shows the graph of an even $360^{\circ}$ - clockwise rotation within 10 seconds. The z-axis shows a leap from $180^{\circ}$ to $-180^{\circ}$ at 5 seconds. This leap is due to the form of 
representation, which is outlined above, and shows that graphs which lie on these two extreme values describe a high level of agreement of the respective selected image section.

Figure 4. Experimental Setup: VR Glasses with Coupled smartphone and Attitude-sensors
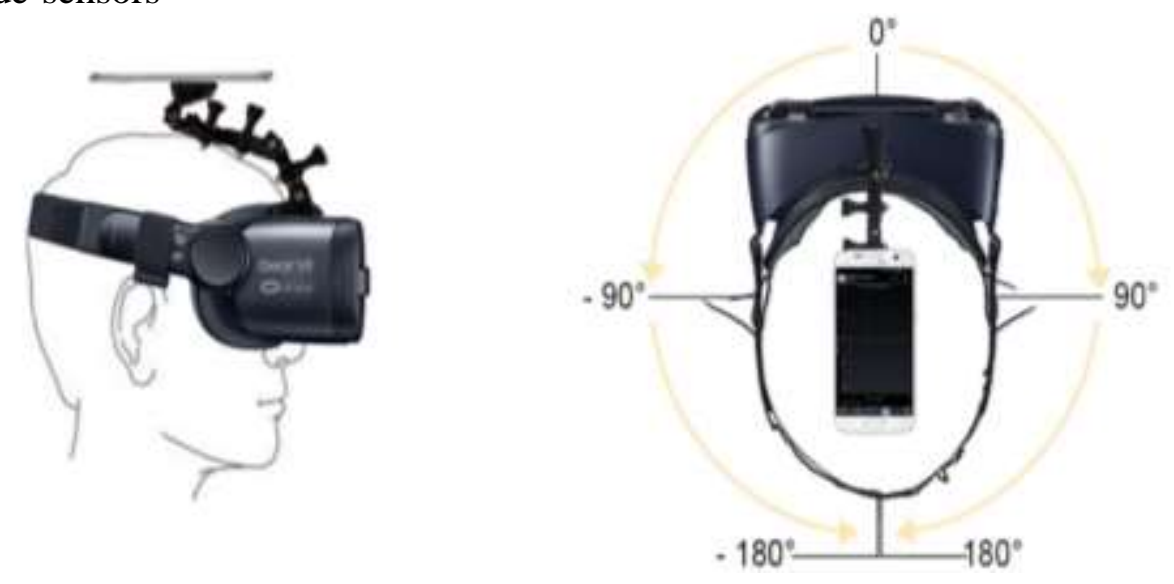

Figure 5. Visualization of a $360^{\circ}$ Rotation around the Vertical Axis

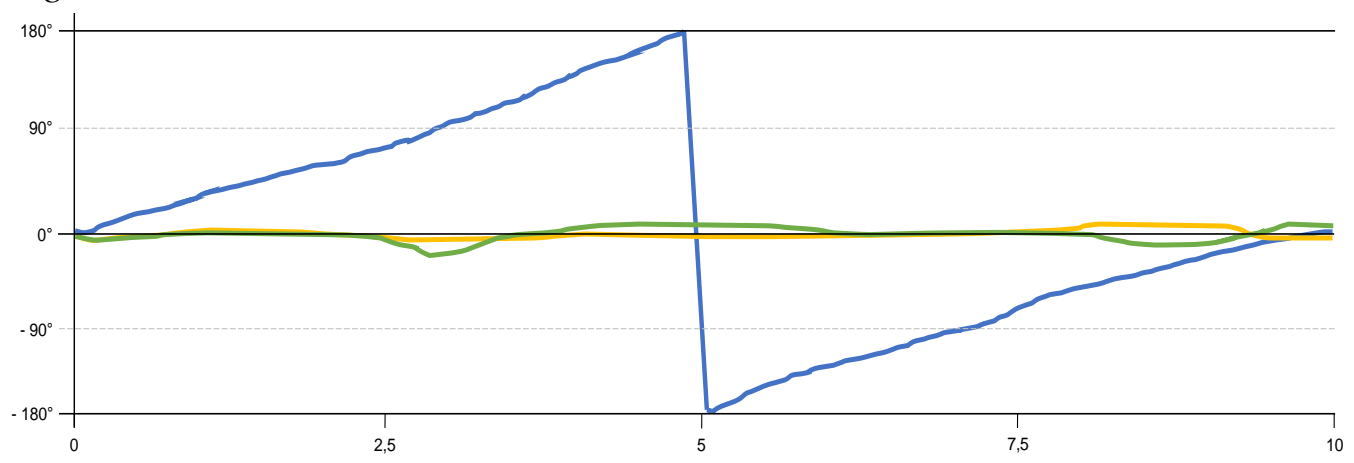

The test participants were selected according to the previously defined target group and an evenly distributed gender ratio. For the trial, 40 subjects were divided into two groups, as the two selected $360^{\circ}$ commercials were played out in reverse order on a pair of VR glasses while the head movements were being recorded in real-time with the use of rotation sensors. Since the actions of both spots exclusively occur at the z-axis level, the evaluation was limited to the analysis of these very data (Figures 6 and 7).

\section{Reception Behavior in the $360^{\circ}$ Advertising Spot by BMW}

The BMW commercial is comprised of a guided story in which progress and resolving are bound to the vehicles. Despite the recipients' free choice of the image section, the analysis of their head movements/viewing directions displays a similar pattern for all subjects (Figure 6). 
Figure 6. Visualization of the Subjects' Head Movements during the Reception of the BMW Spot

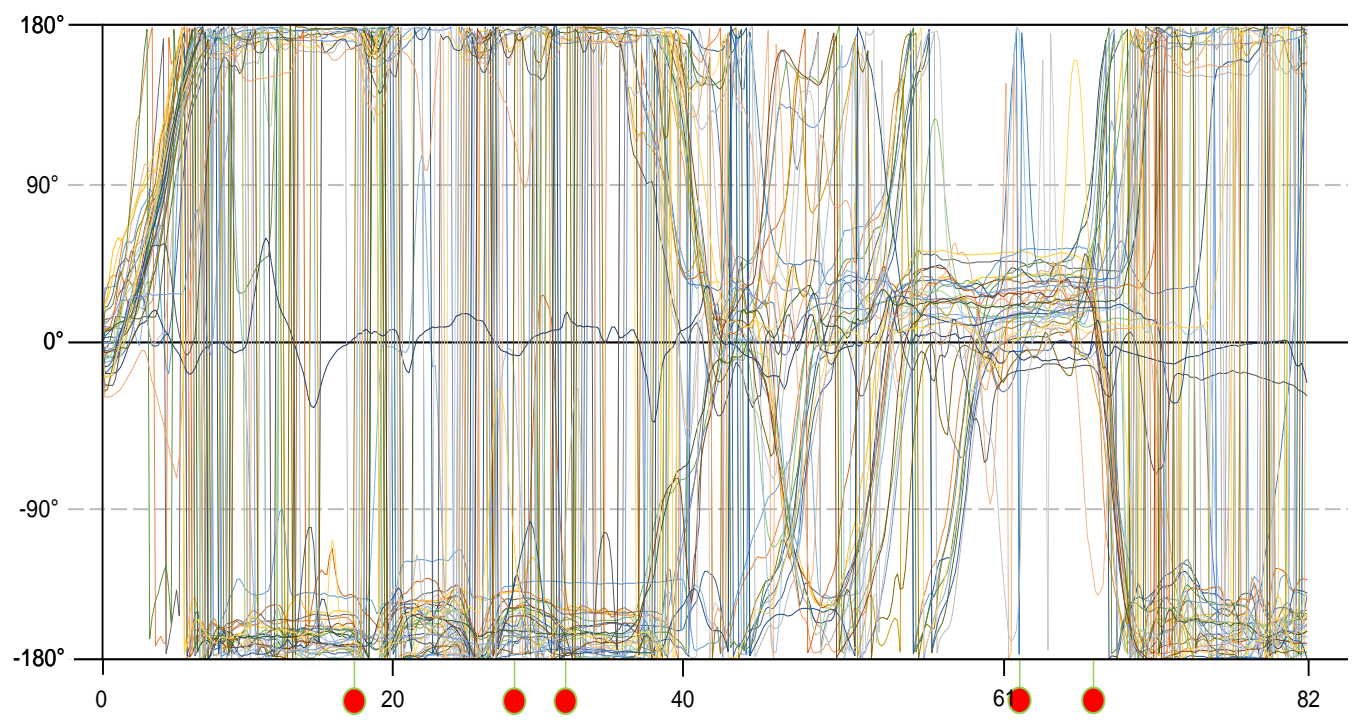

Figure 7. Visualization of the Subjects' Head Movements at the Reception of the VW Spot
$180^{\circ}-1$

First of all, the subjects follow the testimonial in a clockwise rotation of about $190^{\circ}$. The individual deviations are only a few degrees above the vast majority of 40 subjects. As the video proceeds up to second 40, this line of sight is maintained by the subjects. Along with the end of the second formation, i.e. the third milestone, the viewing directions of the subjects diverge. This is due to the fact that the recipients follow different vehicles in the "cap game", passing by the viewer's position from all sides. At the start of the third formation (approximately 55 seconds), the recipients' attention is directed on to one central point again, in order to focus on one of the five vehicles which is, at the end of the spot, moving parallel and eventually coming to a halt. 
Only one subject (see blue line in Figure 6) diverges from the sketched pattern by moving his head only a little bit around the starting position on the $0^{\circ}$ line. As a reason for this, the ensuing survey identified a combination of non-existent knowledge about the reception opportunities, as well as a hitherto unknown immersion experience which leaves the person in astonishment in the situation in question. "

\section{Reception Behavior in the $360^{\circ}$ Advertising Spot by VW}

As already described in the spot analysis above, Volkswagen uses a different concept in the "Immer mittendrin" - spot in comparison to the selected BMW spot: the spectator is the center of the action, everything revolves around him and there are only few clues. Storytelling relies on the non-linear approach. A structured action recedes within the plot in order to "use" the whole space that is to be individually explored by the recipients. This concept is confirmed by the observed reception behavior of the test participants. As can be seen in Figure 7, the viewing directions of the subjects diverge after the first few seconds of the spot without an inter-individual pattern formation.

First of all, the vast majority of the respondents follow the performer, who detaches herself from a group and moves towards the camera in the starting line of sight. This uniform pattern is maintained until the first milestone (the first cameracut) and only then runs apart inter-individually. This means that this actress serves as a clue in the first few seconds and attracts attention. But this pattern dissolves with the first cut and the increasing number of actors. The spot offers opportunities for exploration and discovery in all viewing directions, and the viewer's behavior corresponds. The second marked milestone (second camera cut at the final part) at the end of the spot is followed by a clearly recognizable pattern formation. Although it takes a few seconds for this pattern to form, three clear accumulations can be seen. These three collecting points at the end of the spot are formed only a few seconds after the camera switching to the logos. Here, a logo was placed on each of the spots where the four vehicles had previously been shown. Since there are only three collections of four logos/vehicles, it seems likely that the spectators only noticed three vehicles, which is an assumption being confirmed by a subsequent survey of the test persons.

All in all, the spot also reveals a pattern of reception that is characterized by the high inter-individual difference.

\section{Reception Experience}

Following the reception of the two selected $360^{\circ}$ advertising spots, we interviewed the respondents regarding their reception experience. Using the item "Repeat interest" we wanted to draw conclusions about how stimulating the subjects perceived the two $360^{\circ}$ videos as a whole, while the items "fun" and "fear" deal with specific reception aspects: "Fun" highlights the entertaining character of advertising in the sense of an "infotainment" (Klöppel, 2008) while "fear" stands out against the particularity of the $360^{\circ}$ space, in which users can also 
"lose" themselves and which, due to the required sense orientation, may also lead to an overstraining on parts of the recipients.

Since the occurrence of "cyber-sickness" is described as a frequent concomitant phenomenon in connection to the usage of VR glasses, e.g. Lawson (2015) and it cannot be ruled out that such impairments affect the response of the above-mentioned items, we have finally questioned the participants' well-being.

In fact, some subjects felt dizzy (Figure 8). There is no connection between this occurrence and the variable "fear". Only one recipient combines a strong feeling of fear with the reception of one of the two spots. This is the subject who stood out with the comparatively motionless head posture during the reception of the video. The VW spot was the first to be viewed by the latter, and this can be interpreted as a reason for fear being perceived here and no longer in the BMW spot that was subsequently consumed: The fear-indicating "surprise moment" of the immersive media experience during the reception of the VW spot was already known in the second video.

Figure 8. Survey Result Regarding the Reception Experience (Blue: BMW; Grey: VW)

\begin{tabular}{|c|c|c|c|c|c|c|c|c|c|c|}
\hline \multirow{2}{*}{ 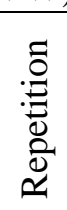 } & \multicolumn{2}{|c|}{$\begin{array}{l}\text { I would like } \\
\text { to repeat }\end{array}$} & \multicolumn{2}{|c|}{$\begin{array}{c}\text { I would rather } \\
\text { repeat }\end{array}$} & \multicolumn{2}{|c|}{$\begin{array}{c}\text { I cannot } \\
\text { decide }\end{array}$} & \multicolumn{2}{|c|}{$\begin{array}{l}\text { I would } \\
\text { rather not } \\
\text { repeat }\end{array}$} & \multicolumn{2}{|c|}{$\begin{array}{c}\text { I would not } \\
\text { repeat }\end{array}$} \\
\hline & 15 & 3 & 16 & 15 & 3 & 6 & 6 & 12 & 0 & 4 \\
\hline \multirow{2}{*}{$\underset{7}{\Xi}$} & \multicolumn{2}{|c|}{$\begin{array}{c}\text { I had a lot } \\
\text { of fun }\end{array}$} & \multicolumn{2}{|c|}{$\begin{array}{l}\text { I had rather } \\
\text { fun }\end{array}$} & \multicolumn{2}{|c|}{$\begin{array}{l}\text { I cannot } \\
\text { decide }\end{array}$} & \multicolumn{2}{|c|}{$\begin{array}{c}\text { I had rather } \\
\text { no fun }\end{array}$} & \multicolumn{2}{|c|}{ I had no fun } \\
\hline & 14 & 7 & 20 & 17 & 3 & 9 & 2 & 6 & 1 & 1 \\
\hline \multirow{2}{*}{ बैँ } & \multicolumn{2}{|c|}{$\begin{array}{c}\text { I was not } \\
\text { afraid }\end{array}$} & \multicolumn{2}{|c|}{$\begin{array}{l}\text { I was rather } \\
\text { not afraid }\end{array}$} & \multicolumn{2}{|c|}{$\begin{array}{l}\text { I cannot } \\
\text { decide }\end{array}$} & \multicolumn{2}{|c|}{$\begin{array}{c}\text { I was rather } \\
\text { afraid }\end{array}$} & \multicolumn{2}{|c|}{ I was afraid } \\
\hline & 34 & 35 & 5 & 4 & 0 & 0 & 0 & 0 & 0 & 1 \\
\hline \multirow{2}{*}{$\begin{array}{l}\tilde{U} \\
\stackrel{\leftrightarrow}{N} \\
\stackrel{N}{0}\end{array}$} & \multicolumn{2}{|c|}{ I was fine } & \multicolumn{2}{|c|}{$\begin{array}{l}\text { I was rather } \\
\text { fine }\end{array}$} & \multicolumn{2}{|c|}{$\begin{array}{l}\text { I cannot } \\
\text { decide }\end{array}$} & \multicolumn{2}{|c|}{$\begin{array}{c}\text { Ifelt rather } \\
\text { bad }\end{array}$} & \multicolumn{2}{|c|}{ I felt bad } \\
\hline & 16 & 20 & 15 & 12 & 3 & 1 & 6 & 6 & 0 & 0 \\
\hline
\end{tabular}

As far as the item "fun" is concerned, the clearly divergent ratings for the BMW and VW spot become apparent. Since the vast majority of respondents first came into contact with immersive media technology $\left(360^{\circ}\right.$ video on VR glasses) in the context of the underlying study, we interpret the differences with regards to the fun experience in the manner that an orientation in space, as conveyed by the linear concept of storytelling in the BMW-Spot, is positively appreciated. Especially by participants without sufficient experience within this media format, whereas a non-linear concept, which may have a different demand for consciousness and is still lacking patterns (Herbst, 2008), performs comparatively worse. 


\section{Summary and Outlook}

The 360 degree video format "is able to involve the viewer in the narrative through various technical aspects. These measures, when used in combination with specific narrative elements, can incite a greater response from viewers compared to traditional video format" (Elmezeny et al., 2018, p. 10). Considering advertisements, it is important that the emotions and experiences conveyed by a story radiate onto the product and the brand. The more relevant the message, the more relevant it is to the recipient and the more precisely the communication can be tailored. In this matter, $360^{\circ}$ videos offer specific opportunities due to the possibility of the individual's exploitation of a space of action which can be tied in with personal interests and previous experience more closely. On the other hand, the free selection of the image section makes it difficult to guide the user in the sense of an intended story (Pope, Dawes, Schweiger \& Sheikh, 2017).

In the present study, we selected two $360^{\circ}$ advertising spots from the automotive industry with linear and non-linear storylines, recorded the reception behavior of the head movements of participants and finally asked for the experiences of reception. The result shows that storytelling in $360^{\circ}$ videos is possible; that users follow a linear storyline during the reception and interindividually follow clues and lastly, that an individual exploration of space is mostly omitted. In a non-linear design, on the other hand, the opportunities of exploration created within the medium break through and necessitate an individualized spatial development. Other than guided access, this places different demands upon the recipients and, especially so for users with little or no experience in the reception of immersive media technologies (here: $360^{\circ}$ video through VR glasses), can probably lead to an overstraining and thus have a negative effect on the overall reception experience. Future follow-up studies must demonstrate whether the observed effect levels out with an increasing user experience.

\section{Bibliography}

Díaz-Kommonen, L., Vosmeer, M., Lee, J. H., Pham, S., Bassbouss, L., \& Mancianti, A. (2018). $360^{\circ}$-Video Storytelling and Virtual Reality Workshop. Proceedings of the 2018 ACM International Conference on Interactive Experiences for TV and Online Video (TVX; 2018) (pp. 253-254). New; York: ACM.

Dörner, R., \& Steinicke, F. (2013). Wahrnehmungsaspekte von VR. In R. Dörner, W. Broll, P. Grimm \& B. Jung, Bernhard (Hrsg.). Virtual und Augmented Reality (VR/AR). Grundlagen und Methoden der Virtuellen und Augmentierten Realität (S. 33-64). Berlin, Heidelberg: Springer.

Elmezeny, A., Edenhofer, N., \& Wimmer, J. (2018) Immersive Storytelling in 360 Degree Videos: An Analysis of Interplay Between Narrative and Technical Immersion. Journal For Virtual Worlds Research, 11(1), 1-13.

Götze, J. (2016). BMW plustert den 2er auf. Reihen-Sechszylinder mit 370 PS, SechsgangHandschaltung und Heckantrieb - so steht der heiß erwartete BMW M2 ab April 2016 beim Händler (BMW puffs up the 2 Series. Series six-cylinder with $370 \mathrm{hp}$, six- 
speed manual transmission and rear-wheel drive - so is the highly anticipated BMW M2 from April 2016 at the dealer). Retrieved from https://bit.ly/2KPLvvL.

Gocht, P. (2016). 6 Tipps für das Storytelling bei $360^{\circ}$-Filmen (6 Storytelling Tips for $360^{\circ}$ Movies). Retrieved from https://bit.ly/2zF7rVT.

Hebbel-Seeger, A. (2017). Innovative Videoformate im Sport. Markenkommunikation mit 360-Grad und VR (Innovative video formats in sports. Brand communication with 360 degrees and VR). In J. Förster, A. Hebbel-Seeger, T. Horky \& H.-J. Schulke (Eds.), Sport und Stadtentwicklung (Sports and Urban Development). (S. 316-346). Aachen: Meyer \& Meyer.

Hebbel-Seeger, A. (2018). $360^{\circ}$-Video in Trainings- und Lernprozessen $\left(360^{\circ}\right.$ video in training and learning processes). In. U. Dittler \& C. Kreidl (Eds.), Hochschule der Zukunft - Zukunft der Hochschule (University of the Future - Future of the University). (S. 269-296). Heidelberg: Springer.

Herbst, D. G. (2008). Storytelling. Konstanz: UVK.

Herbst, D. G., \& Musiolik, T. H. (2016). Digital Storytelling. Spannende Geschichten für interne Kommunikation, Werbung und PR (Digital storytelling. Exciting stories for internal communication, advertising and $P R$ ). Konstanz \& München: UVK.

Klöppel, M. (2008). Infotainment. Zwischen Bildungsanspruch und Publikumserwartung. Wie unterhaltsam darf Information sein? (Infotainment. Between educational claim and audience rating. How entertaining may information be?). Marburg: Tectum.

Lawson, B.D. (2015). Motion Sickness Symptomatology and Origins. In K. S. Hale \& K. N. Stanney (Eds.), Handbook of Virtual Environments: Design, Implementation, and Application (pp. 531-599). Boca Raton: CRC Press.

Lescop, L. (2017). Narrative Grammer in 360. In W. Broll (Eds.), Adjunct Proceedings of 2017 IEEE International Symposium on Mixed and Augmented Reality (ISMARAdjunct) (pp. 254-257). New York: IEEE.

Miller, C. H. (2013). Digital storytelling: A creator's guide to interactive entertainment. Burlington: Focal Press.

Pope, V. C., Dawes, R., Schweiger, F., \& Sheikh, A. (2017). The Geometry of Storytelling: Theatrical Use of Space for 360-degree Videos and Virtual Reality. Proceedings of the 2017 CHI Conference on Human Factors in Computing Systems (CHI 2017) (pp. 4468-4478). New York: ACM.

Schobelt, F. (2016). Grabarz \& Partner: VW Up: "Immer mittendrin" im 360-Grad-Video (Grabarz \& Partner: VW Up: "Always right in the middle" in the 360-degree video). Retrieved from https://bit.ly/2KNXs53.

Scholz, H. (2016). Akzeptanz von Virtual Reality: Deutschland auf dem letzten Platz (Acceptance of Virtual Reality: Germany in last place). Retrieved from https://bit.ly/ 2BOTYMR.

Singer, M. J., \& Witmer, B. G. (1998). Measuring Presence in Virtual Environments: A Presence Questionnaire. Presence: Teleoperators and Virtual Environments, 7(3), 225-240.

Slater, M., \& Wilbur, S. (1997). A Framework for Immersive Virtual Environments (FIVE): Speculations on the Role of Presence in Virtual Environments. Presence: Teleoperators and Virtual Environments, 6(6), 603-616.

Theobald, T. (2016). BMW-M2-Launchkampagne. Fünf Sportwagen, ein Supermodel und das rasanteste Hütchenspiel der Welt (BMW M2 launch campaign. Five sports cars, a supermodel and the fastest shell game in the world). Retrieved from https://bit.ly/ 2QuI6rw. 
Volkswagen Media Services. (2016). Die junge Zielgruppe im Visier: Volkswagen startet Digital-Kampagne des neuen up! (Targeting the young target group: Volkswagen launches digital campaign of the new up!). Retrieved from https://bit.ly/2RAR9EN.

Vosmeer, M., \& Schouten, B. (2014). Interactive cinema: Engagement and interaction. In A. Mitchell, C. Fernández-Vera \& D. Thue (Eds.), Interactive Digital Storytelling (pp. 140-147). Bern: Springer. 



\title{
The Web as an Alternative Communication Resource for Pro-Biafra Independent Movements in Nigeria: The Case of Indigenous People of Biafra
}

\author{
By Emmanuel Sunday Nwofe ${ }^{*} \&$ Mark Goodall ${ }^{\dagger}$
}

\begin{abstract}
The web has become an important platform for social Movement communication. This paper seeks to: (1) examine the extent to which the IPOB Movement, one of the prominent social Movements in Nigeria, appropriates its websites to communicate oppositional interpretations and discourses that capture the essential essence of its struggles for Biafran Independence; (2) assess the communication practices on the websites and the extent to which they enhance the capacity of the Movement to advance its cause, counter anti-Biafra propaganda and challenge State oppression; (3) empirically analyse patterns of communication practices of the web and provide a theoretical connection to how the Movement's websites contribute to building a radical democratic public sphere in Nigeria. The results show that a mix of alarm and outrage with trolling mechanism were significant repertoire of resistant communication by which the Movement walked itself to the frontline of public discourse in Nigeria's public sphere. It is found that the websites (1) provided information relevant for micro mobilisation; (2) serve as a hub for native reporting and radical content production and (3) serve as a channel for documenting graphic evidence of victimhood and contestation of issues relating to the Nigeria democracy and Biafra independent struggle. However, the study notes a varying degree of focus in the main agenda of the Movement, which is mobilising support for referendum to determine Biafran union with Nigeria. The paper concludes that although the websites serve as a hub for circulating oppositional interpretations of events which are of interest to the Movement, there is limited evidence to suggest communication of articulate objective of the Movement for observers' evaluation. The implication of this for African social movements is discussed.
\end{abstract}

Keyswords: alternative media theory, Biafra movement, internet communication, IPOB websites, radical democracy, social movement.

\section{Introduction}

One of the most prominent pro-Biafran Movements, the Indigenous People of Biafra (IPOB) Movement is remarkable in the extent to which digital media technology played a central role in its organisation and mobilisation. The IPOB is a secessionist Movement, which seeks to break away from Nigeria and form an independent nation of Biafra. This plan is not new. On May 30, 1967, Igbo ${ }^{31}$ leaders declared a Biafran state, which led to a brutal civil war that ended on January 15, 1970 (Onuoha, 2018). Nevertheless, the idea of Biafra separatism has continued to ferment, leading to several secessionist Movements in the past. The

\footnotetext{
*Research Student, University of Bradford, UK.

${ }^{\dagger}$ Senior Lecturer, University of Bradford, UK.

${ }^{31}$ The Igbo is the third most dominant ethnic group in Nigeria, native to the present-day of south-central and southeastern Nigeria.
} 
IPOB is currently the most prominent Movement in the line of Movements taking up the cause. The Movement wants the Nigerian government to organise a referendum in the style of the British's "Brexit" referendum, to determine whether the people of Biafra still want to remain in Nigeria.

The digital media activities of the Movement came to prominence in 2015, following the arrest and incarceration of its leader, Mr Nnamdi Kanu, a British Nigerian, by President Mohammadu Buhari. Prior to his incarceration, Mr Kanu, through his radio Biafra FM transmissions from London, repudiated in strong words the alleged lop-sidedness of Nigeria's socio-political structures, double standards and lawlessness. The arrest of Kanu exacerbated pro-Biafra consciousness among the ethnic Igbos, culminating in widespread protest Movements within Nigeria and many countries of the world, including the UK, US, France, Italy, Germany, Malaysia etc. Through digital activities of the Movement, Biafra became a metaphor for discussing national leadership failure and a symbol of a collective aspiration to restructure Nigeria into a representative democracy. The Movement's heavy reliance on the Internet to keep afloat the evidence of political marginalisation resonated within its constituency, where prominent politicians and stakeholders have begun to identify and lend their influence to the Movement, in order to retain their legitimacy with the people. The Movement utilised an ecology of Internet resources, one of which is the web, for mass education and mobilisation. Various commentators have argued that the Internet, and especially the web, provides an effective form of activist media, wherein activists counterbalance the dynamic of mainstream media reporting, which, in their view, disregards the broader context of protest Movements (Atton, 2004; Lievrouw, 2011; Wall, 2003). The Internet can play a variety of roles for social Movement organisations, including the provision of information, assisting in action and mobilisation, promoting interaction and dialogue, enabling literal linkages as well as promoting fundraising and resource generation (Stein, 2009, pp. 752-753). While some scholars have argued that the Internet promotes a deliberative communicative public sphere in the Habermasian perspective (Salter, 2013), by which citizen deliberation can lead to the formation of a rational public sphere, Dahlgren (2005) argues that such theorisation fails to account for what defines legitimate deliberation. As such, a social Movement media can espouse "discursive radicalism" and inter-discursive conflict" (Dahlgren, 2005, p. 47) that can affect its success or failures. In the context of the IPOB Movement, it is interesting to ask if the Movement's alternative media contributed to understanding Biafra independence struggle, or just the lived realities of apparent marginalisation and exclusion of the people that walks the Movement to the frontline of political activism in Nigeria. The purpose of this paper is to: (1) examine the extent to which the IPOB Movement appropriated its websites to communicate oppositional interpretations and discourses that capture the essential essence of its struggles for Biafran Independence; (2) assess the communication practices on the websites and the extent to which they enhance the capacity of the Movement to advance its cause, counter anti-Biafra propaganda and challenge state oppression; (3) empirically analyse patterns of communication practices of the web and provide a theoretical connection to how the Movement's websites 
contribute to building a radical democratic public sphere in Nigeria. Specifically, the paper poses the following questions:

1. How does the IPOB Movement use the web to communicate primary collective issues?

2. To what extent does the IPOB Movement use the web to counter antiBiafra information, advance its cause and challenge state oppression?

3. How do the IPOB websites contribute to building agonistic radical democratic politics in Nigeria's public sphere?

Drawing mainly on alternative and radical democratic theories, this paper offers additional insights into African social movements and the use of the Internet. It further brings into focus the text-based communication elements that explain variations in how social Movements in Africa communicate grievances online in the context of IPOB. By assessing the linguistic and discursive mechanisms under which activists interpret grievances, the paper contributes to an understanding of "activists-centred layer" of Internet use that can enrich the understanding of the Internet as a site of struggle. Such an approach of rhetorical analysis contributes to a better understanding of Movement's communicative phenomena on the web (Schneider \& Foot, 2004)

\section{Literature Review}

\section{The Theoretical and Empirical Backdrop of Social Movements Communication in the Mass Media}

The rise of protest Movements and the contributions of digital media have inspired both academic and public attention to the dynamic relationships between social Movements and their medium of communication. Commentators have described social Movements as key platforms by which to raise discreet social and political issues, which the market and states have elected to keep secret (Stein, 2009). Hence, the communication process is integral to their success (Atton, 2004; Evans, 2016). Research has shown that communicating through the mainstream media has become especially dialectic (Boykoff, 2006; 2013), as mainstream media focus on undesirable actions that affect a Movement's legitimacy in the public sphere. Boykoff (2013) identified five causal mechanisms by which the transactional interaction between state and mass media can "animate the process of social Movement demobilisation" (p. 5). One such mechanism is the "resignification process" by which mass media coverage can change the underlying beliefs that make up the discourses and frames used by Movement actors thereby shaping which set of beliefs are salient and " altering the meaning of actors" interest that generally affects the power of a particular discourse or frame" (Boykoff, 2013, p. 5). Movements can only get adequate mainstream media 
coverage if they employ dramatic or disruptive tactics, however, undesirable (Evans, 2016), because journalists have privileged "tactics" more than a Movement's goals (Boyle, McLeod, \& Armstrong, 2012).

Consequently, communication scholars have suggested that the Internet constitutes a crucial alternative resource for social Movement's communication (Atton, 2004; Lievrouw, 2011), providing communication opportunities not available in the mainstream media or alternative form of Movements' media (Castells, 2015) and creating "emancipatory communication practices" that challenge dominant powers in the communication and media field (Akser, 2015, p. 2). Social Movements can rely in large measure on networked communication technologies to organise and disseminate alternative information that supports their objectives (Conover et al., 2013). Not only that, social Movement can bypass mainstream gatekeeping and communicate directly with their constituents and the broader public. However, the cost of doing so is also possibly reduced (Garrett, 2006). Moreover, the Internet can facilitate the transnational character of Movements, by "effectively and rapidly diffusing communication and mobilisation efforts" across borders (Van Laer \& Van Aelst, 2010, p. 1146). With the proliferation of social media, social Movements are much more obligated to produce issue-based content with which to meet increasing public expectations to access information from Movement's sources (Harlow, 2012), or to provide conflict early warning signals to government.

While contemporary research has largely focused on the role of social media as an alternative platform for communicating social activism (Enjolras, SteenJohnsen, \& Wollebæk, 2013; Gerbaudo, 2018; Sandoval-Almazan \& Gil-Garcia, 2014), scholars have failed to represent much clearly the importance of websites in the contemporary social activism. In other words, social Movement literature still offers thin descriptions of the actual communication practices of Movements' websites, even when this is still of interest to those who theorise the political value of the Internet as a communication resource (Stein, 2009). Few available research has been " incremental and ad-hoc" (Earl \& Garrett, 2017, p. 479), with analytical toolbox that "does not include a systematic theorising of the communicative side of social unrest" (Mattoni, 2017, p. 495). Furthermore, social Movement literature has not offered much description on how contemporary social Movements in Africa are using the websites as communication resource, much less Nigeria. Websites are complex platforms that go beyond text in their appeals, incorporating other technologies and software applications such as video, audio, images, graphics and instant chat that favour horizontal and participatory communication and dissemination of information. Social Movements' websites can provide capacity for activists and bystanders to search and retrieve archived information, which can enhance the continuity of collective action and discourses in the increasingly visual digital public sphere. It is of interest to understand their newscreation practices and analyse how such practices work to sustain oppositional culture and/or limit Movements' success in the broader public sphere. 


\section{The Internet as Alternative Media}

The Independent Media Centres (IMC), otherwise known as Indymedia, in the early 2000s, heralded a new type of media activism that sparked academic interest in alternative media, as well as the Internet as a platform for radical politics. Proponents of Indymedia claim that they provide an alternative to the agendas, politics, economics, reporting practices, and ethics of mainstream news organisations, and are thus the direct descendants of "alternative" or "radical" news media (Lievrouw, 2006, p. 5). In the literature, the definition of alternative forms of media is characterised by different interpretations. Some scholars prefer to employ different labels, such as "critical media" (Fuchs, 2010), "radical media" (Downing, 2000), "activist new media" (Lievrouw, 2011), or citizen media (Rodriguez, 2000). Whichever label depends on the locus of study and the emphasis a scholar wants to promote, but also denotes a strong relationship between alternative media and activism. In other words, alternative media play an important role in educating activists, promoting an oppositional interpretation of events of interest, mobilising constituents, prompting action and creating an identity (Rauch, 2007). The political motivation behind the development of such alternative spaces is to give activists and supporters the opportunity to express their concerns, show their interest and discuss local and global issues relevant to their struggles (Platon \& Deuze, 2003). Research has shown that it is an only alternative form of media that reports the strengths and legitimacy of social Movements, casting a positive light on activists as against the mainstream media, whose reports tend to be non-sympathetic (Cissel, 2012).

A great deal of critical discussion revolves around the Internet and the public sphere paradigm developed by Jürgen Habermas. With criticisms thereto, the Internet is thought to advance a public sphere of equal deliberation and pluralism, thus providing the resources for the "counter-public sphere" (Downey \& Fenton, 2003; Gimmler, 2001; Salazar, 2003).

The IPOB websites constitute an example of the counter-public sphere in the sense that they produce radical communicative interactions that diffuse into other channels of digital communication. Activists initiate most oppositional debates and discourses including the failure of leadership, inequitable political structures and the dictatorial approach of government to their struggles on the websites. Such media practice adds to enriching the debate about good governance, equality and justice in the Nigerian public sphere. Research has suggested that a lot of Movements are using digital communication platform's alternative resources for social activism (Harlow \& Harp, 2013; Poell, 2014; Poell \& Borra, 2012). Harlow and Harp (2013)'s analysis of activists' use of alternative media, suggests that activists were positive about the role of the Internet as an alternative public sphere for staying informed and for waging activism. In Chile, social Movement organisations have relied on hybrid alternative media ecology in their activism (Jofré, 2017). This is the same in Hong Kong, where Yung and Leung (2014) found the Internet as alternative media resources that encourage civil society activism, by facilitating and enlarging "active online counter-public" (Leung \& Lee, 2014, p. 340). While alternative media can be said to offer a voice to the 
voiceless: "voice as a process and voice as a value" (Atton, 2015), it can be argued that it is not enough for the Internet to offer a voice to a social Movement, such a voice must carry concomitant value in the wider process of social change. In that perspective, we argue that while the websites can provide alternative communication resources for the IPOB Movement, it is expected that interactions should add value to the cause of the struggle, in ways that not only accommodate differences, but also promote the web as a platform for social mobilisation in Nigerian society.

\section{The Internet as a Radical Democratic Public Sphere}

The concept of radical and agonistic public sphere helps us explain the dialectic in online communications of the IPOB's websites. Specifically, the concept sheds light on the bitter, caustic, vituperative and unequivocal discourses, which characterise the Movement's web communication. Contrary to the model of deliberative democracy, which emphasises a strong link between democracy and liberalism - based on inclusive normative consensus or "communicative rationalism", the radical or agonistic perspective views politics as intrinsically conflictual and non-consensual, placing differences and contestation at the heart of the democratic system (Dahlberg, 2007a; Mouffe, 2000). Dahlberg (2007a) argues that counter-discourses emerge in response to exclusion. And so, fragmentation into like-minded groups allows for articulation and identification of issues, which have been excluded from, and thus stand in opposition to, dominant discourses. Such fragmentations, he argues, contribute to the plurality of counter-discourses that are beneficial to democracy.

Various commentators have argued that the Internet's contribution to democratic politics is mainly in the promotion of agonistic public sphere (Bennett \& Pfetsch, 2018; Dahlberg, 2007b; Dahlberg \& Siapera, 2007; Kellner, 1999). Agonistic public sphere is a model of democratic politics, which acknowledge the dimension of antagonism that the pluralism of values entails and its ineradicable character (Mouffe, 2000). This entails the expression of emotions, especially hatred, resentment, anger and compassion, both on the Internet and in the news media, by which conflicting interests are contested and paradoxes in society are exposed (Tong, 2015, p. 333). The agonistic public sphere considers the Internet's capacity to account for the democratic role of politics associated with excluded voices. In this line of argument, the emphasis is not how much individuals deliberate with differently positioned others. Instead, "the focus is on the formation of counter-discourses online and the extent and effects of inter-discursive contestation" (Dahlberg, 2007a, p. 839). Emphasis on the democratic role of contestations from a mainstream public sphere, which the Internet supports. In fact, the radicalness of agonistic pluralism lies in its aim to recognise differences and to ascribe rights, to reach out to as many friends as possible, while retaining the necessary contestation and sheer struggle of politics (Hands, 2007).

The IPOB activists espoused agonistic deliberation in different ways. First, their communication discourses are replete with rumours, abuses and stereotype. Second, they do not allow a nuanced argument around Biafran independence that 
crave for an informed debate. Instead, they tend to attack any contrary opinion to their approaches. Third, they promote narratives that do not account for the role of Igbo politicians in the situation they are in, blaming other ethnic groups in almost everything. Some authors argue that dispersion and cacophony of public voices have led to a "disruptive public sphere" that is unable to communicate across difference (Bennett \& Pfetsch, 2018). The Internet as a contested terrain allows for contentious claims and discourses to flourish in the public sphere, encouraging antagonistic politics to mushroom, as diverse group are able to voice dissentious opinion online. From the agonist literature, Dahlberg (2007b) summarised the role of Internet in supporting agonistic democratic politics. First, the internet support marginalised voices to "develop their own deliberative spaces that draw upon and strengthen marginalised discourses". Second, the Internet is deemed to help in "linking up with other excluded voices in developing representatives, strategically [facilitating] effective counterdiscourses". Third, the Internet contributes to subsequent "contestation of meanings and practices dominating mainstream public sphere".

\section{Methods}

In order to examine the dynamics of communication practices on IPOB websites, this paper adopted a web-based content analytical approach - a method that combines qualitative and quantitative approaches in analysing communication characteristics. First, the researcher identified the main websites used by the Movement by searching the links included on the Movement's blog www.ipob.org. Second, the researcher obtained additional information by interviewing activists as part of a larger research study examining the impact of new media technology on IPOB Movement. Ultimately, three online news platforms: Biafra Times, Biafra Herald and Biafra Telegraph were sampled based on their unique features, which will allow for the examination of archival information. Each website sampled has a link to archived publications and articles arranged according to the months of publication. The scope of the study was between October 2015 (when the Movement came to prominence following the arrest and incarceration of its leader) and April 2017 (when the leader was released on bail), a total of 20 months. The reason for this choice is that this period is the height of active and radical communication exchange between the Movement and the Nigerian authority and will allow for better understanding of the use of their websites to disseminate and share alternative and critical content and information. The homepage constitutes the unit of analysis. The reason for this is twofold. First, websites can contain hundreds of pages and thousands of textual and multimedia files which can pose a number of "unrealistically demanding" problems in coding (Ben Moussa, 2011). Second, a homepage constitutes the first point of entry in a website, possessing many central and organisational elements of web design that are "attention-grabbing" (Ben Moussa, 2011, p. 133). Furthermore, due to the potential of the web to accommodate a large number of textual items, the study 
adopted a purposive sampling of 15 items per month, resulting in 300 items per news source. Finally, 900 articles were analysed and coded.

\section{Coding}

Drawing on the topology of communication function as developed by Stein (2009), we coded and categorised the textual items according to issues they raised, while also focusing on the radicalism or otherwise of the communication content in terms of their value for mobilising social change. Following Saldaña (2015), which explains various coding methods, we further adopted the subsequent coding methods: Descriptive Coding (to note the topic written about); In vivo Coding (to note the specific qualitative evaluative feature of text); Narrative Coding (to note stories and how they are retold in the text); Evaluation Coding (to reflect on the nature and content of the inquiry); and "Theming data" (to capture the meaning of an aspect of data using phrase or sentence) (Adu, 2016). Thereafter, we sorted the codes based on their relationship and frequencies, and synthesised them under four main categories: 1) whether communication provides information; 2) whether the text communicates injustices; 3 ) whether communication creates an identity, or 4) whether communication prompts action (action and mobilisation). In each main category there are sub-categories, which further highlights the specific issues of interest in the Movement's media practice. The codes generated by activists' communication content were slightly modified, which suggests its reliability. We attained additional reliability check by the agreement of two coders: the researcher and another research student.

\section{Results and Discussion}

\section{Quick Summary}

In a quick summary, Table 1 shows that information variables were mostly reported, followed by variables promoting action or mobilisation. Variables on identities were less reported.

Table 1. Case-Processing Summary

\begin{tabular}{|l|c|c|c|c|c|c|}
\hline \multirow{2}{*}{} & \multicolumn{4}{|c|}{ Cases } & \multicolumn{3}{c|}{ Total } \\
\cline { 2 - 7 } & \multicolumn{2}{|c|}{ Valid } & \multicolumn{2}{c|}{ Missing } & \multicolumn{3}{c|}{ Ta } \\
\cline { 2 - 7 } & $N$ & $\%$ & $N$ & $\%$ & $N$ & $\%$ \\
\hline IPOB Websites * Information & 309 & 34.3 & 591 & 65.7 & 900 & 100.0 \\
\hline IPOB Websites * Injustice & 232 & 25.8 & 668 & 74.2 & 900 & 100.0 \\
\hline IPOB Websites * Identity/Culture & 71 & 7.9 & 829 & 92.1 & 900 & 100.0 \\
\hline IPOB Websites * Action \& Mobilisation & 288 & 32.0 & 612 & 68.0 & 900 & 100.0 \\
\hline IPOB Websites * Linguistic Tone & 900 & 100.0 & 0 & 0.0 & 900 & 100.0 \\
\hline
\end{tabular}




\section{Information: Alarms as Repertoire of Resistant Communication Strategy}

The analysis demonstrates a cross-mix of information on the websites. Our Initial coding produced eight themes under which the Movement used the web to provide diverse information (Table 2).

Table 2. Thematic Components of Information* IPOB Websites Cross Tabulation Count

\begin{tabular}{|l|c|c|c|c|}
\hline \multirow{2}{*}{} & \multicolumn{3}{|c|}{ IPOB Websites } & \multirow{2}{*}{ Total/(\%) } \\
\cline { 2 - 4 } & $\begin{array}{c}\text { Biafran } \\
\text { Telegraph }\end{array}$ & $\begin{array}{c}\text { Biafran } \\
\text { Herald }\end{array}$ & $\begin{array}{c}\text { Biafran } \\
\text { Times }\end{array}$ & \\
\hline Incompetence/Abuse of Office & 28 & 19 & 28 & $\mathbf{7 5 / ( 2 4 . 3 )}$ \\
\hline Raising the Alarm & 18 & 26 & 19 & $\mathbf{6 3 / ( 2 0 . 4 )}$ \\
\hline $\begin{array}{l}\text { Inaccurate Reporting, Propaganda/ } \\
\text { Media Silence Conspiracy }\end{array}$ & 10 & 19 & 15 & $\mathbf{4 4 / ( 1 4 . 2 )}$ \\
\hline Ineffective Representation & 9 & 13 & 16 & $\mathbf{3 8 / ( 1 2 . 3 )}$ \\
\hline $\begin{array}{l}\text { MNK, IPOB Leadership \& } \\
\text { NeoBiafranism }\end{array}$ & 9 & 10 & 9 & $\mathbf{2 8 / ( 9 . 1 )}$ \\
\hline International Conspiracy/Silence & 8 & 7 & 9 & $\mathbf{2 4 / ( 7 . 8 )}$ \\
\hline Hypocrisy of/ Reason for One-Nigeria & 5 & 7 & 11 & $\mathbf{2 3 / ( 7 . 4 )}$ \\
\hline Court Updates/Appearances & 5 & 4 & 5 & $\mathbf{1 4 / ( 4 . 5 )}$ \\
\hline Total & $\mathbf{9 2}$ & $\mathbf{1 0 4}$ & $\mathbf{1 1 2}$ & $\mathbf{3 0 9 / ( 1 0 0 \% )}$ \\
& $(\mathbf{2 9 . 8 \% )}$ & $\mathbf{( 3 4 \% )}$ & $\mathbf{( 3 6 . 2 \% )}$ & \\
\hline
\end{tabular}

Two main areas were outstanding: reporting incompetence and raising the alarms. Analysis also shows that the websites feature counter reporting against unfavourable information from anti-Biafra elements, or expression of dissatisfaction over unfavourable reporting of the media or lack of it. Others include information relating to ineffective representation of Biafran politicians, information on the true nature of IPOB leadership and the adroitness of Nnamdi Kanu, and information on why Nigeria does not want Biafra to be independent. The websites were also used to update the court cases of IPOB activists held in custody.

Significantly, the result suggests that reports analysing the systemic failures of political culture in Nigeria were prominent. Across the three websites, analysis demonstrates that interpretations of events within Nigerian bureaucratic politics feature areas of weaknesses and failures, arguably, suggesting the tendency to frame Nigeria as a failed State. Issues of abuse of office featured prominently and consistently in the communicative discourses as well as framing of President Buhari as an incompetent leader. Example: "The Nigerian Bureau of Statistics (NBS) says the total number of Nigerians who became unemployed within the first and second quarter of 2016 now stands at 2.6 million. This brings the total freshly unemployed persons in the economy to a record high of 4,580,602, since President Muhammadu Buhari took office in May 2015" (BiafraTelegraph, June 2016). This article is supported by a photograph presenting President Buhari as someone without brains (suggesting that he lacks intelligence and skills of governance).

Activists gather news reports or opinion articles published in the mainstream media that analysed weaknesses, abuse of office or incompetence of President 
Buhari's government. This approach seems significant in diffusing anti-Buhari sentiments among the adherents of Biafra and also builds a radical understanding of why Biafra independence is the key. In what Allam (2014) calls repertoire of "virtual dissidence", the weaknesses of public authorities and political structures of a country could be used as a locus of a struggle, by encouraging collective actions against it in the virtual public spaces of the Internet.

One significant finding of this study is that activists' prominently used the strategy of raising the alarm as useful mechanism to communicate primary collective concerns, which also represents an effective repertoire of resistant communication practice against military repression. With the affordances of digital technologies, alarms are sometimes supported with graphic photos or videos of military brutality (Figure 1). While it is possible that some of these alarms have the tendency of being untrue as they could be based on rumours, fear and distrust arising from the repressive approach of the Nigerian government, this strategy enabled the Movement to provoke human rights discourse within and beyond Nigeria and appeals to the ideological and emotional sentiments of its constituent. By circulating graphic evidence of military attacks and killing of members, the websites serve as a reference point for human rights organisations including Amnesty International. Activists first raised the alarm of the disappearance of their leader when he was first arrested and claimed the Nigerian government could not have agreed to having him in custody if activists had not circulated intelligence reports about his arrest online (Tochukwu, 2015). Another prominent alarm was raised to alert the world on the increasing disappearance and killing of supporters by the Nigerian military. Social Movement scholars have used the concept of the repertoire of contention to denote various means by which people engage in oppositional discourse against the status quo. A repertoire comprises what people know they can do when they want to oppose a public decision they consider unjust or threatening (Della Porta, 2013). In the definition developed by Charles Tilly, the repertoire of contention includes "a whole set of means a group has for making claims of different types on different individuals" (Della Porta, 2013). In a political environment, activists employ a certain form of action considered appropriate to express their objectives. For the IPOB Movement, the repressive character of the Nigerian government earns it certain kinds of authority over its claims of victimhood. Reports consistently showed overwhelming outrage within the Movement's constituency over the manner in which unarmed peaceful protesters are killed in their numbers and sometimes thrown in the sea or left in the bush without any investigation (Amnesty International, 2016; Precious, 2016). 
Figure 1. One of the Graphic Evidence of Torture to Support Alarms

PICTURE: PRO-BIAFRANS STRANGLED BY NIGERIAN ARMY

O AT 02:20:00 $E$ AFRICA, FEATURED, WORLD NEWS,

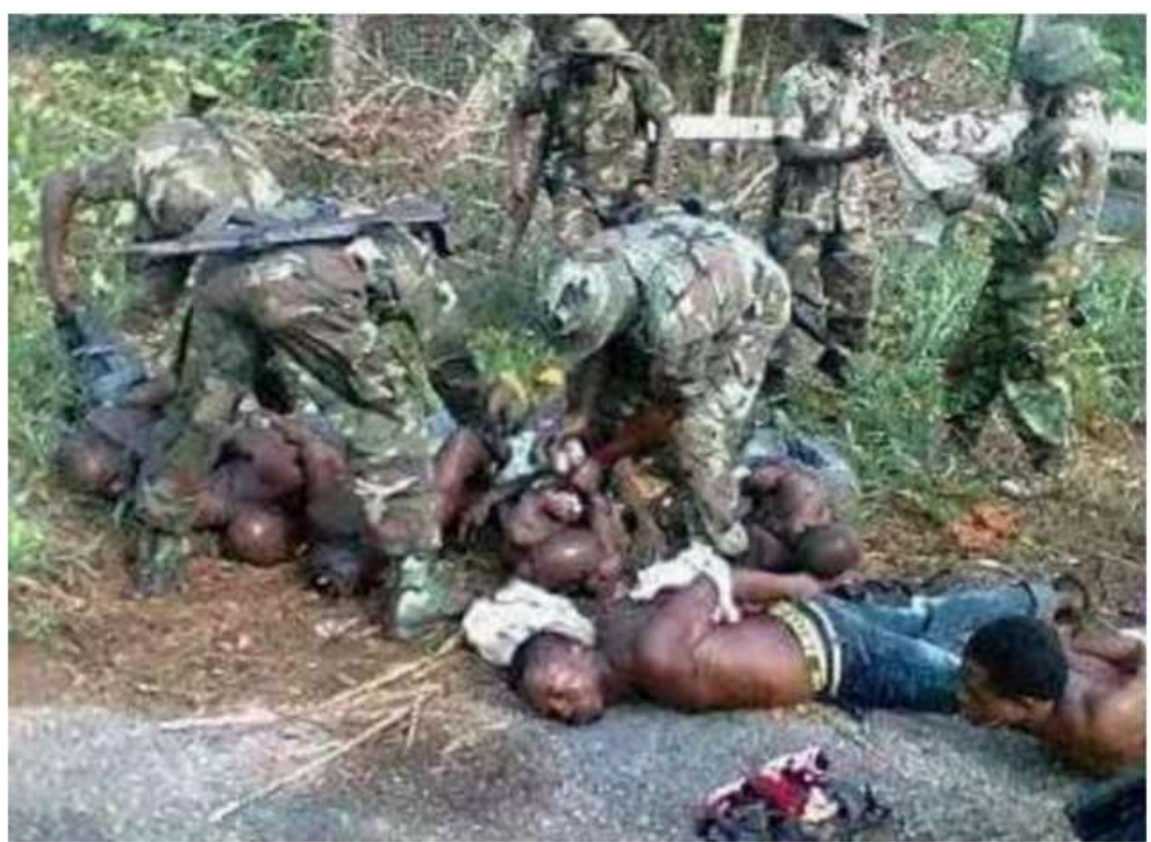

Source: Biafra Telegraph.

Activists use alarms to give new information over unfolding events. They can get classical information that helps them overcome the repressive character of government. When this is the case, activists are encouraged to flood the Internet with claims that will put Nigerian government or concerned person in the defence. Example includes: (1) "Biafra: Mark Zuckerberg sponsored by Buhari to thwart Biafra restoration" (Ogbu, 2016), (2) "EXCLUSIVE: Nigerian Lady Writes Mark Zuckerberg Via DHL, Accuses Facebook of Helping Buhari to Crackdown on Opposition Voices in Nigeria" (BiafraHerald, 2016a), (3) "Information from a reliable source has revealed that MTN Telecommunication Company has joined alliance with the Nigerian government to track down all phone calls and text messages of IPOB members and other genuine Pro-activists working tirelessly for the restoration of Biafra" (Alagba, 2016). These reports arise from fear that the Nigerian government could use the CEO of Facebook or the MTN network to track down activists. Before this, they have raised the alarm that the Nigerian security agencies are tracking and arresting activists through their mobile network. Again, report also goes that the Movement's account was deleted on Facebook platform soon after the CEO visited President Buhari. In some cases, activists are encouraged to stop using the MTN network. In a very creative way, activists used the tactics of alarm to counter anti-Biafran reports, lack of media coverage and media conspiracy on Biafran Movement. 


\section{Action and Mobilisation: Using the Web as Effective Counter-Discourses}

Our result also shows that IPOB Movement appropriated the websites to develop counter-hegemonic praxis aimed at prompting action and mobilise support within and beyond Nigeria society. Table 3 has a summary of variables under action and mobilisation.

Table 3. Thematic Components of Action \& Mobilisation* IPOB Websites Cross Tabulation

\begin{tabular}{|l|c|c|c|c|}
\hline \multirow{2}{*}{} & \multicolumn{3}{|c|}{ IPOB Websites } & \multirow{2}{*}{ Total/(\%) } \\
\cline { 2 - 4 } & $\begin{array}{c}\text { Biafran } \\
\text { Telegraph }\end{array}$ & $\begin{array}{c}\text { Biafran } \\
\text { Herald }\end{array}$ & $\begin{array}{c}\text { Biafran } \\
\text { Times }\end{array}$ & \\
\hline $\begin{array}{l}\text { Mobilising International } \\
\text { Support/Awareness }\end{array}$ & 23 & 28 & 31 & $\mathbf{8 2 / ( 2 8 . 5 )}$ \\
\hline $\begin{array}{l}\text { Motivation Action/Unity of } \\
\text { Purpose }\end{array}$ & 16 & 24 & 30 & $\mathbf{7 0 / ( 2 4 . 3 )}$ \\
\hline $\begin{array}{l}\text { History \& Progress of } \\
\text { Movement }\end{array}$ & 14 & 26 & 13 & $\mathbf{5 3 / ( 1 8 . 4 )}$ \\
\hline Referendum/Restructuring & 19 & 8 & 5 & $\mathbf{3 2 / ( 1 1 . 1 )}$ \\
\hline Literal Linkages & 6 & 14 & 8 & $\mathbf{2 8 / ( 9 . 7 )}$ \\
\hline Protest Match & 11 & 6 & 6 & $\mathbf{2 3 / ( 8 )}$ \\
\hline Total & $\mathbf{8 9}$ & $\mathbf{1 0 6}$ & $\mathbf{9 3}$ & $\mathbf{2 8 8 / ( 1 0 0 )}$ \\
\hline
\end{tabular}

Of particular interest are variables, which show that $28.5 \%$ of publications either targeted towards mobilising international support or motivated connective action within Movement's constituents. There is better opportunity for visual connection between Movement's action and the actions of its opponents. Specifically, the analysis focuses on the text that communicates or proposes action and initiatives aimed at achieving specific actions. For example, actions such as motivating activists to sign and share petitions; to tweet evidence of human rights abuses to international stakeholders; announcing or scheduling protest marches, updating the Movement's action plan/progress of struggles etc., are consistent on the websites. In all of these, a tactical mix of alarms and outrage with emotional resources provided a radical atmosphere, which allowed for the contestation of issues, positions and approaches of the Nigerian government to the activists.

The analysis also suggests that communication reinforced internal cohesion by focusing on items that motivate activists to action. Communication focused on the main purpose of the struggle and why activists should not be distracted by antiBiafran elements. As part of educating prospective supporters, the history and progress of the Movement are consistently analysed, notwithstanding some framing tactics that could potentially be untrue. For example, articles such as: "Let Biafra Go, Donald Trump Sends Strong Message to Buhari" (Igbonews, 2016), or "Biafra: if the people of Biafra want Republic of Biafra, it will be a reality during my administration" - Donald Trump (BiafraHerald, 2016b). Communication such as this boggles the mind but also encourages pro-Biafran supporters to hope for Biafra restoration. The IPOB is one of the groups that organised a solidarity rally for Donald Trump after winning the US elections. Their action is in the belief that he would recognise their independent Movement. Many discourses on the web 
tend to give hope to Biafran independence supporters that Trump has assured the IPOB that he will support their Movement to ensure the reality of a Biafran state. This might just be the imagination of a few actors to raise the hope of participants. In what Castells (2009) calls "practice of spin" - formatting messages to bring about most interesting biases that resonate with supporters, the Internet knit together comments and opinions that could sustain a struggle. During the antiWorld Trade Organisation, Van Laer and Van Aelst (2010) showed that activists used the web to disseminate opinions, videos, audio, text and photos, enabling activists to provide coverage and putting up analysis and context to counterbalance the poor US corporate media coverage of the WTO meeting. This analysis focuses on communications taking place on the web and generally examined how such communication supports the cause of Biafra Independence. Significantly, not much information focused on referendum or restructuring, as this only accounted for $11 \%$. This, arguably, suggests that although the Movement presents referendum as major demands, there is no coordination in articulating such demands on its websites. Communications are extravagantly focused on varied issues and do not follow any consistent logic. The analysis notes about $9.7 \%$ of communications literally linking the Movement to other freedom fighters within and outside Nigeria (for example, Movement for the Independence of southern Ambazonia in Cameroon, Niger Delta Avengers, Adaka Biafra Marine Commandos etc.).

\section{Communicating Injustice: Trolling Mechanism and Radical Communication}

The third category is the Injustice frame. Our analysis shows that the Movement used the websites to report and condemn various forms of injustices meted on the activists and their constituents. Injustice is at the core of social Movements' repertories and the Internet has brought the greater possibilities for victims of injustice to mobilise collective outrage and cause sympathy by serving as a link to both organised and dispersed actors in processes of social mobilisation. In this study, as shown in Table 4, there are five variables under which injustice frames were analysed. Significantly, reports focus mainly on human rights abuses $(34.1 \%)$, the dictatorial culture of the Nigerian government and the suppression of dissent voice by President Buhari (30.6\%), and injustices relating to Fulani Herdsmen killing of innocent farmers across the country with relative inaction towards tackling it by the Nigerian government (17.2\%).

Of significant interest also is that injustices specifically focusing on the marginalisation only accounted for $7.3 \%$. This, again, shows lack of coherent communication logic that brings out clearly the Movement's main issues. It is clear that the Internet only reinforced the lived reality of the people and help them visualise issues that resonate with them. Essentially, people are just fed up with their situation and have decided to alter the condition by joining the Movement rather than the Internet being a causal factor.

Significant use of human rights narratives has become critical elements of social Movement repertoire, especially in the developing world (Osaghae, 2008). On the websites, reports on the arrest and killing of IPOB activists are consistent, including reactions from the International community and rights groups. Digital 
media platforms circumvent government's ability to block some information from getting to the public sphere. With digital media tools on the hands of activists, protest Movements and other activities of the organisation are sometimes livestreamed on social media and posted on websites, which attracts widespread attention to the Movement. Such videos are sources of reference for mainstream media journalists. Such graphic evidence provides justification and organising principles that bring coherence to the idea of discrimination, inequalities and justice within the Nigerian political system.

Table 4. Thematic Components of Injustice * IPOB Websites Cross Tabulation

\begin{tabular}{|l|c|c|c|c|}
\hline \multirow{2}{*}{} & \multicolumn{3}{|c|}{ IPOB Websites } & \multirow{2}{*}{ Total/(\%) } \\
\cline { 2 - 4 } & $\begin{array}{c}\text { Biafran } \\
\text { Telegraph }\end{array}$ & $\begin{array}{c}\text { Biafran } \\
\text { Herald }\end{array}$ & $\begin{array}{c}\text { Biafra } \\
\text { Times }\end{array}$ & \\
\hline Human Right Abuse & 30 & 24 & 25 & $\mathbf{7 9 / ( 3 4 . 1 \% )}$ \\
\hline Dictatorship/Suppression of Dissent Voice & 23 & 27 & 21 & $\mathbf{7 1 / ( 3 0 . 6 \% )}$ \\
\hline Allowing Herdsmen Terrorism & 22 & 11 & 7 & $\mathbf{4 0 / ( 1 7 . 2 \% )}$ \\
\hline Divide \& Rule/ Prejudice & 6 & 4 & 15 & $\mathbf{2 5 / ( 1 0 . 8 \% )}$ \\
\hline Marginalisation & 6 & 3 & 8 & $\mathbf{1 7 / ( 7 . 3 \% )}$ \\
\hline Total & $\mathbf{8 7}$ & $\mathbf{6 9}$ & $\mathbf{7 6}$ & $\mathbf{2 3 2 / ( 1 0 0 \% )}$ \\
\hline
\end{tabular}

In communicating different forms of injustices, our analysis identified trolling mechanism as a factor, which may have potentially walked the Movement to the frontline of political discourse in Nigeria. The term "trolling" has recently changed to mean not only the provocation of Internet users but the abuse of them too (Bishop, 2014). Trolling describes the increasing spate of unethical behaviours in the Internet community. This includes flaming, profanity, insults and deception. Research has shown that cyber- trolling is a direct manifestation of everyday sadism (Buckels, Trapnell, \& Paulhus, 2014). There is evidence to suggest that the IPOB activists manifest their everyday frustration in their publications. Our analysis shows high tendencies of communication being abusive or ultimately insulting or deceptive. We noted some examples:

1. "Mbaka is now sabotaging indigenous people of Biafra efforts at freedom and restoration of Biafraland. As soon as Aisha, the girl raped by Buhari visited him in his adoration shrine, Mbaka like Balaam raised several devilish alters against Biafra protesters and IPOB leadership. It should be recalled that the sole administrator of [the] Islamic Republic of Nigeria released 20 billion nairas to the media, individuals and clergy to blackmail the Biafra struggle. Mbaka has as usual eaten the food sacrificed to demons and is now playing the harlot" (Orji, 2015).

2. "How the Child rapist Buhari Is Trying to Use Nigerian Senate to Resurrect His Infamous Decree 4" (BiafraTimes, 2015).

Comments like these suggest the level of provocative communication against those who may have not supported the group in one way or another. The data suggests a tendency towards user-generated-racism - a form of communication that attempts to demonise everything and everybody except 
that which supports Biafran discourse. Social Movements in Africa tend to take similar character, as communication is generally antagonistic and illogical. People are more likely to communicate their frustrations using uncivilised words. However, a repertoire of disobedient actions tends to attract more attention and reactions, especially in the context of Nigeria. We argue that this style of communication may have been responsible for the kind of attention received by the Movement. Considering the fact that Nigerian government is less responsive to conflict early warning signs until inconsequential situation becomes a full-blown conflict, transgressive expressions may have become a tactical repertoire that brought the Movement to public knowledge while also, appeared to have prevented the more nuanced individuals from participating or identifying with the struggle. Table 5 shows an overwhelming character of sensationalism in activists' communication on the websites.

Table 5. IPOB Websites * Linguistic Tone Cross Tabulation

\begin{tabular}{|l|c|c|c|c|}
\hline \multirow{2}{*}{ IPOB Websites } & \multicolumn{3}{|c|}{ Linguistic Tone } & \multirow{2}{*}{ Total/(\%) } \\
\cline { 2 - 5 } & Highly Abusive & Partially Abusive & $\begin{array}{c}\text { Generally } \\
\text { sensational }\end{array}$ & \\
\hline Biafran Telegraph & 30 & 34 & 236 & $\mathbf{3 0 0}$ \\
\hline Biafran Herald & 64 & 37 & 199 & $\mathbf{3 0 0}$ \\
\hline Biafran Times & 55 & 21 & 224 & $\mathbf{3 0 0}$ \\
\hline Total & $\mathbf{1 4 9 / ( 1 6 . 6 \% )}$ & $\mathbf{9 2 / ( 1 0 . 2 \% )}$ & $\mathbf{6 5 9} /(\mathbf{7 3 . 2 \%})$ & $\mathbf{9 0 0 / ( 1 0 0 )}$ \\
\hline
\end{tabular}

Benford and Snow (2000) argue that the credibility of collective action frame among Movement's constituent is an important factor in frame resonance. In this argument, the emphasis is not "whether the diagnostic and prognostic claims are factual or valid but whether their empirical referents lend themselves to being read as real indicators of diagnostic claims" (Benford and Snow, 2000, p. 620). In other words, is there something out there that can be pointed to as evidence of the claims embedded in the framing? The slices of evidence on the websites is an important resonance that appeals to some segments of the prospective or actual adherents of Biafra. According to Castells (2015), the Internet turns raw responses into a Movement of political importance, by facilitating the trajectory from outrage to hope and to action. IPOB activists invoked the narrative of human rights to build, articulate and mobilise pro-Biafra sentiments, with a tactical mix of alarms and trolling mechanisms. Bishop (2014) argues that for long time the mass media organisations have created a demonised transgressive character to increase the visibility of their audiences living situation as a way of being responsible to their audiences. In the millennial digital communication practices, this style of reporting is taking permanent roots. In the context of the IPOB activists, trolling (arguably) becomes one way of expressing the lived reality of frustrations and grievances with the target of building radical followership and attracting mass media coverage. 


\section{Identity}

Another area of communication on the websites stresses value differentiation and resourcefulness of the "Biafrans". Activists used items expressing cultural identity, ethnic identity and socioeconomic identity of the Biafrans to define the boundaries between "us" and "them"; making a case for a new republic that will be the economic hub of the world. In particular, items expressing religious/ethnic identity take prominence in the three websites, accounting for $49.3 \%$ of the total reports under this category. Ethnic and religious consciousness are factors that have affected Nigeria as a country. This analysis shows expressions communicating how Biafrans have been discriminated, marginalised or attacked based on their religious and ethnic identity. And so, with Biafra the value orientation of the Biafrans as Christians would subsist.

Table 6. Thematic Components of Identity/Culture * IPOB Websites Cross Tabulation

\begin{tabular}{|l|c|c|c|c|}
\hline \multirow{2}{*}{} & \multicolumn{3}{|c|}{ IPOB Websites } & \multirow{2}{*}{ Total/(\%) } \\
\cline { 2 - 4 } & Biafran Telegraph & Biafran Herald & Biafran Times & \\
\hline Religious/Ethnic Identity & 16 & 6 & 13 & $\mathbf{3 5} /(\mathbf{4 9 . 3})$ \\
\hline Political/Economic Identity & 7 & 9 & 2 & $\mathbf{1 8 / ( 2 5 . 4 )}$ \\
\hline Cultural Identity & 9 & 5 & 4 & $\mathbf{1 8 / ( 2 5 . 4 )}$ \\
\hline Total & $\mathbf{3 2}$ & $\mathbf{2 0}$ & $\mathbf{1 9}$ & $\mathbf{7 1 / ( 1 0 0 )}$ \\
\hline
\end{tabular}

Furthermore, the political and economic strength of Biafrans were reported. This emphasises their entrepreneurial ability and resourcefulness. This argument is mostly made in defence of the propaganda that an independent Biafra will be a disaster. Reports tend to creating a strong sense of identity and educating the people that an Independent Biafra will mean freedom, productivity and hard work. Other reports stress the cultural differentiation of the Biafran people, that is value differentiation (Table 6). Social Movement scholars have emphasised that building a sense of identity is a sine qua non for Movement's collective action. With strategic framing, Movements define grievance between "us" and "them" in the structure of conflicts and allies and draw on collective identity frames to shape their mobilisation efforts since a Movement requires solidarity to act collectively, "constructing identities around its claims is one way of doing so" (Tarrow, 2011). The IPOB activists draw on the cultural, religious, economic and political values to construct a Biafran identity.

\section{Conclusion}

This paper has examined the communicative practices of the IPOB Movement on its three main websites. The results suggest that the Movement's web serves as an alternative media platform wherein the invention and circulation of counter-discourses on Biafra as well as Nigeria's politics is permissible. With a strategic mix of alarm and outrage, the IPOB mobilised oppositional interest to the celebrated atrocities of security agents that serve to 
dramatize and render more salient the dictatorial and arbitrary nature of Buhari administration. It is argued that the choice of the repertoire of action is a function of the relationship between the object of claims, the claimant and the environment it is facing: political institutions, elites, mass media, ad-hoc or alternative public space (Teune, 2006). Through a varying degree of radical publication, the IPOB appropriated its web resources to produce a repertoire that aims to raise expectations, arouse feelings, manifest pressures on politicians and government and amplify frames that appear to resonate with their prospective or actual adherents. There is a significant evidence of counterhegemonic publications that are not just correcting misinformation or misrepresentation of the media, government or its agents, but also focused on the failures of leadership in Nigeria. Specifically, the websites (1) provided information relevant for micro mobilisation; (2) serve as a hub for native reporting and radical content production, and (3) serve as a channel for documenting graphic evidence of victimhood. Significant publications focused on mobilising international supports, drawing attention to human rights abuses in Nigeria and the arbitrary nature of President Buhari's government. The study notes a varying degree of focus in the main agenda of the Movement, which is mobilising support for referendum to determine Biafran union with Nigeria. This agenda was not appropriately communicated. Issues were varied and inconsistent, casting doubt on the main agenda of the Movement. However, by focusing largely on the failures of the Nigerian State, human rights abuse and general incompetence and abuse of office, the Movement used the web to create an alternative vision of promoting Nigerian democracy than aiming for an independent Biafra. Moreover, the Movement's radical expressions and investigative role around public officials has further deepened political awareness and expressions in Nigeria's public sphere.

Some potential limitations are noted, as they also suggest direction for future study. First, given that the study is based on the Movement's three main websites, an expansive measure that includes all other channels of Movement's communication can test the extent the Movement is able to articulate its objective on the Internet. Secondly, future work can further test whether the variables identified in this study contribute to the Movement's mobilisation success.

\section{References}

Adu, P. (2016). Qualitative Analysis: Coding and Categorizing Data. NCADE The Chicago School of Professional Psychology.

Alagba, P. I. (2016). Exposing MTN's Alliance with Nigerian Government to Annihilate Biafrans. Retrieved from http://www.thebiafraherald.co.

Akser, M. (2015). Social Movements and their Technologies: Wiring Social Change. London: SAGE Publications.

Allam, N. (2014). Arab Revolutions: Breaking Fear| Blesses and Curses: Virtual Dissidence as a Contentious Performance in the Arab Spring's Repertoire of Contention. International Journal of Communication, 8, 18. 
Amnesty International. (2016). Nigeria: Bullets were Raining Everywhere: Deadly Repression of pro-Biafra Activists. Retrieved from www.amnesty.org.

Atton, C. (2004). An alternative internet. UK: Edinburgh University Press.

Atton, C. (2015). The Routledge Companion to Alternative and Community Media. London: Routledge.

Ben Moussa, M. (2011). The Use of the Internet by Social Movements in Morocco: Implications for Collective Action and Political Change. Concordia University.

Benford, R. D., \& Snow, D. A. (2000). Framing Processes and Social Movements: An Overview and Assessment. Annual Review of Sociology, 26(1), 611-639.

Bennett, W. L., \& Pfetsch, B. (2018). Rethinking Political Communication in a Time of Disrupted Public Spheres. Journal of Communication, 68(2), 243-253.

BiafraHerald. (2016a). EXCLUSIVE: Nigerian Lady Writes Mark Zuckerberg Via DHL, Accuses Facebook of Helping Buhari to Crackdown on Opposition Voices in Nigeria. Retrieved from http://www.thebiafraherald.co.

BiafraHerald. (2016b). BIAFRA: "If the People of Biafra want Republic of Biafra, it will be a Reality During my Administration"-Donald Trump. Retrieved from http://www.thebiafraherald.co.

BiafraTelegraph. (2016, June). Nigreia: 4.58 Million Nigerians have Lost their Jobs under Bubari. Retrieved from http://www.thebiafratelegraph.co.

BiafraTimes. (2015). How the Child rapist Buhari is Trying to use Nigerian Senate to Resurrect his Infamous Decree 4. Retrieved from https://bit.ly/2rk5hql.

Bishop, J. (2014). Representations of "Trolls" in Mass Media Communication: A Review of Media-texts and Moral Panics Relating to "Internet Trolling". International Journal of Web Based Communities, 10(1), 7-24.

Boykoff, J. (2006). Framing Dissent: Mass-media Coverage of the Global Justice Movement. New Political Science, 28(2), 201-228.

Boykoff, J. (2013). The Suppression of Dissent: How the State and Mass Media Squelch US American Social Movements. New York: Routledge.

Boyle, M. P., McLeod, D. M., \& Armstrong, C. L. (2012). Adherence to the Protest Paradigm: The Influence of Protest Goals and Tactics on News Coverage in US and International Newspapers. The International Journal of Press/Politics, 17(2), 127-144.

Buckels, E. E., Trapnell, P. D., \& Paulhus, D. L. (2014). Trolls just want to have Fun. Personality and Individual Differences, 67, 97-102.

Castells, M. (2009). Communication Power. New York: Oxford. University Press.

Castells, M. (2015). Networks of Outrage and Hope: Social Movements in the Internet Age. UK: John Wiley \& Sons.

Cissel, M. (2012). Media Framing: a comparative content analysis on mainstream and alternative news coverage of Occupy Wall Street. The Elon Journal of Undergraduate Research in Communications, 3(1), 67-77.

Conover, M. D., Davis, C., Ferrara, E., McKelvey, K., Menczer, F., \& Flammini, A. (2013). The Geospatial Characteristics of a Social Movement Communication Network. PloS One, 8(3), e55957.

Dahlberg, L. (2007a). Rethinking the Fragmentation of the Cyberpublic: From Consensus to Contestation. New Media \& Society, 9(5), 827-847.

Dahlberg, L. (2007b). The Internet and Discursive Exclusion: From Deliberative to Agonistic Public Sphere Theory. In L. Dahlberg, \& E. Siapera (Ed.), Radical Democracy and the Internet (pp. 128-147). London: Palgrave Macmillan.

Dahlberg, L., \& Siapera, E. (2007). Radical Democracy and the Internet: Interrogating Theory and Practice. London: Palgrave Macmillan. 
Dahlgren, P. (2005). The Internet, Public Spheres, and Political Communication: Dispersion and Deliberation. Political Communication, 22(2), 147-162.

Della Porta, D. (2013). Repertoires of contention. The Wiley-Blackwell Encyclopedia of Social and Political Movements. https://doi.org/10.1002/9780470674871.wbe spm178.

Downey, J., \& Fenton, N. (2003). New Media, Counter Publicity and the Public Sphere. New Media \& Society, 5(2), 185-202.

Downing, J. D. (2000). Radical Media: Rebellious Communication and Social Movements. California, London and New Delhi: SAGE Publications.

Earl, J., \& Garrett, R. K. (2017). The New Information Frontier: Toward a More Nuanced View of Social Movement Communication. Social Movement Studies, 16(4), 479-493.

Enjolras, B., Steen-Johnsen, K., \& Wollebæk, D. (2013). Social Media and Mobilization to Offline Demonstrations: Transcending Participatory Divides? New Media \& Society, 15(6), 890-908.

Evans, E. M. (2016). Bearing Witness: How Controversial Organizations Get the Media Coverage They Want. Social Movement Studies, 15(1), 41-59.

Fuchs, C. (2010). Alternative Media as Critical Media. European Journal of Social Theory, 13(2), 173-192.

Garrett, R. K. (2006). Protest in an Information Society: A Review of Literature on Social Movements and new ICTs. Information, Communication \& Society, 9(2), 202-224.

Gerbaudo, P. (2018). Tweets and the Streets: Social Media and Contemporary Activism. London and New York: Pluto Press.

Gimmler, A. (2001). Deliberative Democracy, the Public Sphere and the Internet. Philosophy \& Social Criticism, 27(4), 21-39.

Hands, J. (2007). Between Agonistic and Deliberative Politics: Towards a Radical Edemocracy. In Radical Democracy and the Internet (pp. 89-107). London: Springer.

Harlow, S. (2012). Social Media and Social Movements: Facebook and an Online Guatemalan Justice Movement that moved Offline. New Media \& Society, 14(2), 225-243.

Harlow, S., \& Harp, D. (2013). Alternative Media in a Digital Era: Comparing News and Information use among Activists in the United States and Latin America. Communication \& Society, 26(4), 25-51.

Igbonews. (2016). Let Biafra Go, Donald Trump Sends Strong Message to Buhari. Retrieved from http://igbonews.co.uk.

Jofré, D. (2017). Social Movements and Media: Unravelling the Communication Practices of Environmental SMOs in Chile (PhD Dissertation). University of Glasgow, UK.

Kellner, D. (1999). Globalisation from below? Toward a Radical Democratic Technopolitics. Angelaki: Journal of the Theoretical Humanities, 4(2), 101-113.

Leung, D. K., \& Lee, F. L. (2014). Cultivating an active online counterpublic: Examining usage and political impact of Internet alternative media. The International Journal of Press/Politics, 19(3), 340-359.

Lievrouw, L. (2011). Alternative and Activist New Media. Malden, MA: Polity Press.

Lievrouw, L. A. (2006). Oppositional and Activist New Media: Remediation, Reconfiguration, Participation. Paper presented at the Proceedings of the 9th Conference on Participatory Design: Expanding Boundaries in Design, Volume 1. 
Mattoni, A. (2017). A Situated Understanding of Digital Technologies in Social Movements. Media Ecology and Media Practice Approaches. Social Movement Studies, 16(4), 494-505.

Mouffe, C. (2000). Deliberative Democracy or Agonistic Pluralism. Social Research, 66(3), 745-758.

Ogbu, C. (2016). Biafra: Mark Zuckerberg Sponsored By Buhari to Thwart Biafra Restoration. Retrieved from http://www.thebiafraherald.co.

Onuoha, G. (2018). Bringing "Biafra" back in: narrative, identity, and the politics of non-reconciliation in Nigeria. National Identities, 20(4), 379-399.

Orji, B. (2015). Mbaka and his Doctrine of Balaam. Retrieved from https://bit.ly/2Q6D MiR.

Osaghae, E. E. (2008). Social Movements and Rights Claims: The Case of Action Groups in the Niger Delta of Nigeria. Voluntas: International Journal of Voluntary and Nonprofit Organizations, 19(2), 189.

Platon, S., \& Deuze, M. (2003). Indymedia Journalism: A Radical Way of Making, Selecting and Sharing News? Journalism, 4(3), 336-355.

Poell, T. (2014). Social Media and the Transformation of Activist Communication: Exploring the Social Media Ecology of the 2010 Toronto G20 protests. Information, Communication \& Society, 17(6), 716-731.

Poell, T., \& Borra, E. (2012). Twitter, YouTube, and Flickr as Platforms of Alternative Journalism: The Social Media Account of the 2010 Toronto G20 Protests. Journalism, 13(6), 695-713.

Precious, E. (2016). The secret murder of Biafrans by the zoo-Nigerian soldiers. Retrieved from http://www.thebiafratelegraph.co/2016/03/the-secret-murder-ofbiafrans-by-zoo.html

Rauch, J. (2007). Activists as Interpretive Communities: Rituals of Consumption and Interaction in an Alternative Media Audience. Media, Culture \& Society, 29(6), 994-1013.

Rodriguez, C. (2000). Civil Society and Citizens Media. Peace Architects for the New Millennium. In K. G. Wilkins (Ed.), Redeveloping Communication for Social Change. Theory, Practice, Power (pp. 147-160). New York, Toronto and Playmouth: Rowman \& Littlefield Publishers, Inc.

Salazar, J. F. (2003). Articulating an Activist Imaginary: Internet as Counter Public Sphere in the Mapuche Movement, 1997/2002. Media International Australia Incorporating Culture and Policy, 107(1), 19-30.

Saldaña, J. (2015). The Coding Manual for Qualitative Researchers. London: SAGE Publications.

Salter, L. (2013). Democracy, New Social Movements, and the Internet: A Habermasian Analysis. In M. Mccaughey, \& M. D. Ayers (Ed.), Cyberactivism (pp. 127-154). London: Routledge.

Sandoval-Almazan, R., \& Gil-Garcia, J. R. (2014). Towards Cyberactivism 2.0? Understanding the use of Social Media and other Information Technologies for Political Activism and Social Movements. Government Information Quarterly, 31(3), 365-378.

Schneider, S. M., \& Foot, K. A. (2004). The Web as an Object of Study. New Media \& Society, 6(1), 114-122.

Stein, L. (2009). Social Movement Web use in Theory and Practice: A Content Analysis of US Movement Websites. New Media \& Society, 11(5), 749-771.

Tarrow, S. G. (2011). Power in Movement: Social Movements and Contentious Politics. UK: Cambridge University Press. 
Teune, S. (2006). Making sense of communication repertoires in the German global justice movements. Paper presented in the Marie Curie Conference and Training Series European Protest Movements since the Cold War: The Rise of a (Trans-) national Civil Society and the Transformation of the Public Sphere after 1945. Retrieved from https://bit.ly/2TGynfR.

Tochukwu, T. (2015). Biafra: Buhari's plans exposed! Retrieved from https://bit.ly/2E8 cmmp.

Tong, J. (2015). The Formation of an Agonistic Public Sphere: Emotions, the Internet and News Media in China. China Information, 29(3), 333-351.

Van Laer, J., \& Van Aelst, P. (2010). Internet and Social Movement Action Repertoires: Opportunities and Limitations. Information, Communication \& Society, 13(8), 1146-1171.

Wall, M. A. (2003). Social Movements and the Net: Activist Journalism goes Digital. In K. Kawamoto (Ed.), Digital Journalism: Emerging Media and the Changing Horizons of Journalism (pp. 113-122). USA: Rowman \& Littlefield Publishers, Inc.

Yung, B., \& Leung, L. Y.-M. (2014). Diverse Roles of Alternative Media in Hong Kong Civil Society: From Public Discourse Initiation to Social Activism. Journal of Asian Public Policy, 7(1), 83-101. 
